c. 3

; Army Corps

Engineers

vvaterways Experiment

Station

Aquatic Plant Control Research Program

\title{
Allocation of Biomass and Carbohydrates in Waterhyacinth (Eichhornia crassipes): Pond-Scale Verification
}

\author{
by John D. Madsen, Kien T. Luu, Kurt D. Getsinger \\ Environmental Laboratory
}




\section{Allocation of Biomass and Carbohydrates in Waterhyacinth (Eichhornia crassipes): Pond-Scale Verification}

by John D. Madsen, Kien T. Luu, Kurt D. Getsinger

Environmental Laboratory

U.S. Army Corps of Engineers

Waterways Experiment Station

3909 Halls Ferry Road

Vicksburg, MS 39180-6199

Final report

Approved for public release; distribution is unlimited 


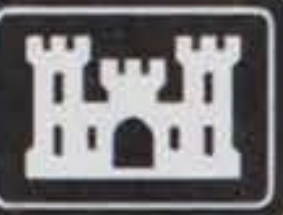

US Army Corps of Engineers

Waterways Experiment Station

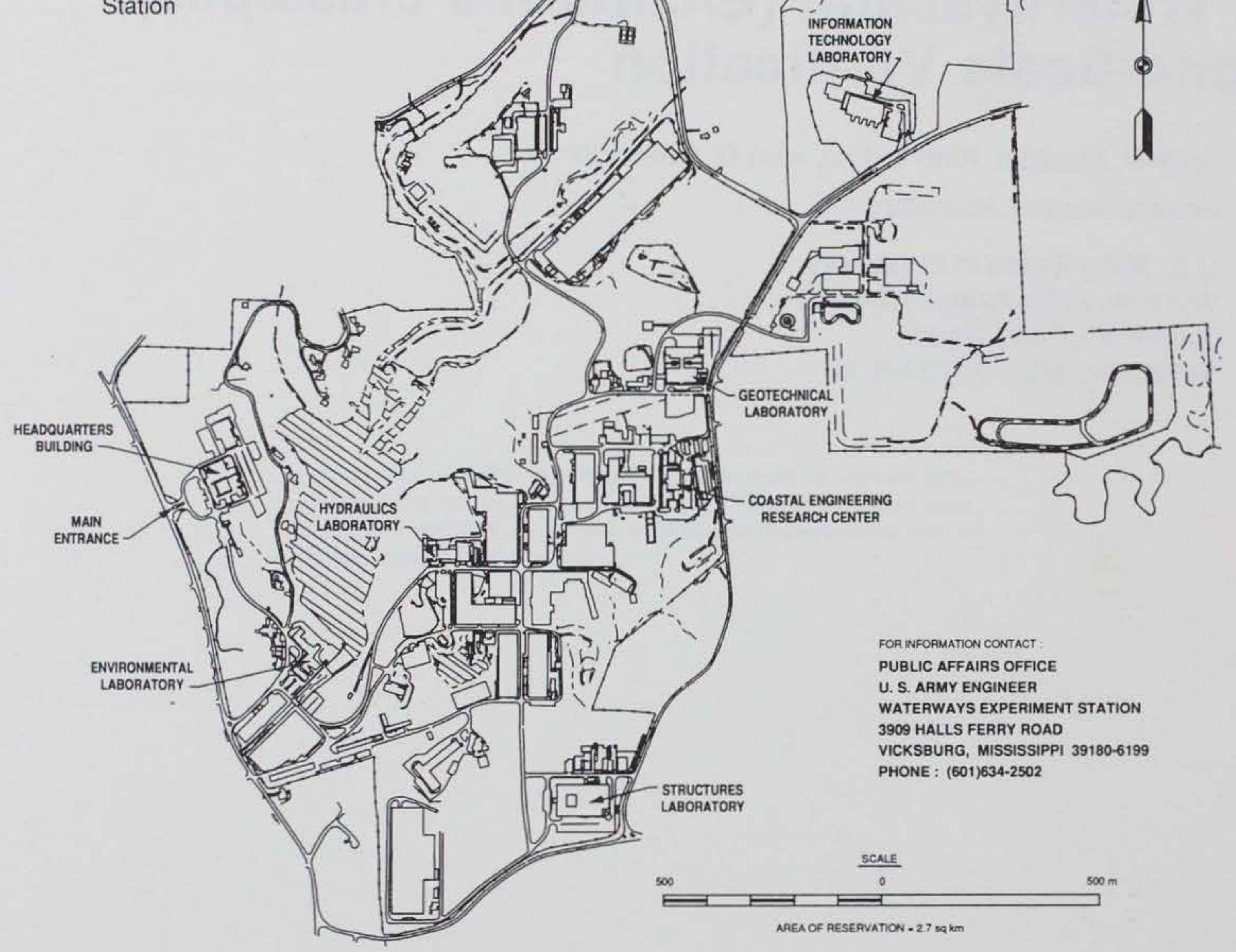

\section{Waterways Experiment Station Cataloging-in-Publication Data}

Madsen, John D.

Allocation of biomass and carbohydrates in waterhyacinth (Eichhornia crassipes) : pond-scale verification / by John D. Madsen, Kien T. Luu, Kurt D. Getsinger ; prepared for U.S. Corps of Engineers.

39 p. : ill. ; $28 \mathrm{~cm}$. - (Technical report ; A-93-3) Includes bibliographical references.

1. Water hyacinth - Growth. 2. Aquatic weeds - Control. 3. Water hyacinth - Nutrition. 4. Aquatic plants - Seasonal variations. I. Luu, Kien T. II. Getsinger, Kurt D. III. United States. Army. Corps of Engineers. IV. U.S. Army Engineer Waterways Experiment Station. V. Aquatic Plant Control Research Program (U.S. Army Engineer Waterways Experiment Station) VI. Title. VIII. Series: Technical report (U.S. Army Engineer Waterways Experiment Station) ; A-93-3. 


\section{Contents}

List of Figures $\ldots \ldots \ldots \ldots \ldots \ldots \ldots \ldots \ldots \ldots \ldots \ldots \ldots \ldots \ldots$

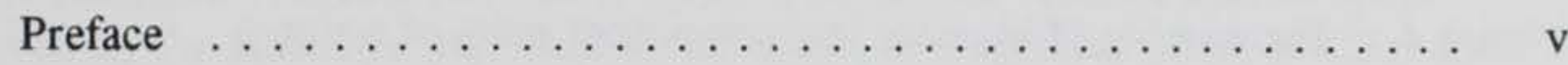

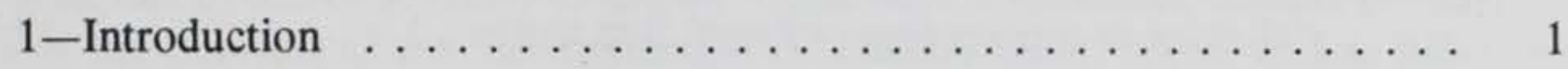

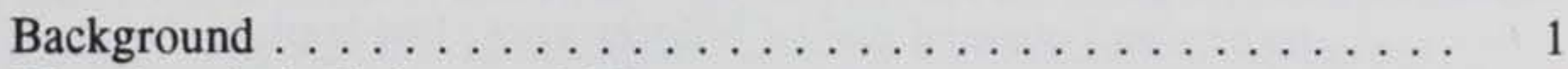

Waterhyacinth Biology and Management ............ 2

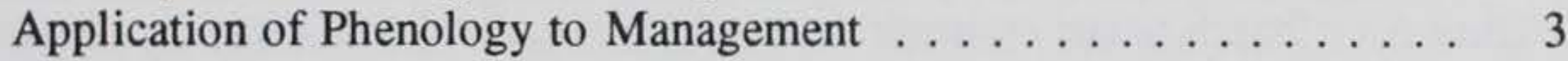

Objectives .................... 5

2-Methods . . . . . . . . . . . . . . . 6

Meteorological Monitoring $\ldots \ldots \ldots \ldots \ldots \ldots \ldots \ldots$

Plant Sampling and Carbohydrate Analysis . . . . . . . 7

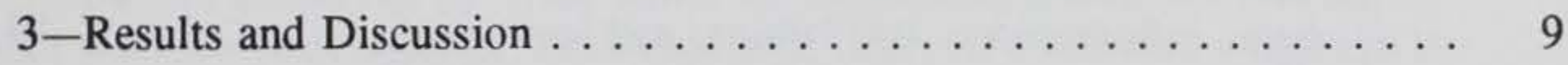

Meteorological Data . . . . . . . . . . . . . . 9

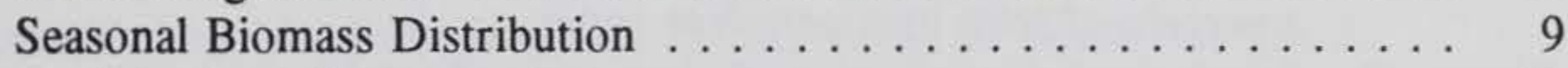

Carbohydrate Concentration ................. 11

Carbohydrate Mass Balance - Mass per Unit Area . . . . . . . . 17

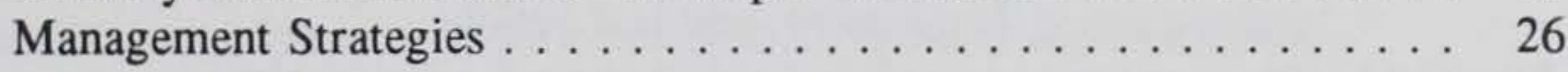

4-Conclusions and Recommendations $\ldots \ldots \ldots \ldots \ldots \ldots$

Conclusions . . . . . . . . . . . . . . . . . . 29

Recommendations .................. 30

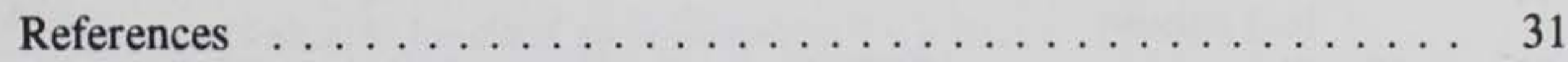




\section{Figures}

Figure 1. Maximum and minimum air temperature, Lewisville Aquatic Ecosystem Research Facility, August 1989-

March $1990 \ldots \ldots \ldots \ldots \ldots$

Figure 2. Major vegetative parts of waterhyacinth $\ldots \ldots \ldots 8$

Figure 3. Biomass of the sum of live mass, dead material, and root and of the stolon, stembase, inflorescence, leaf lamina, and leaf petiole . . . . . . . . . . . . . 10

Figure 4. Partitioning of biomass into component parts of waterhyacinth as a percentage of living mass, and dead material mass as a percentage of total live mass . . . . . . 12

Figure 5. Free sugar tissue concentrations of stolon, stembase, roots, dead material and of inflorescence, leaf lamina, and leaf petiole . . . . . . . . . . . . . .

Figure 6. Starch tissue concentrations of stolon, stembase, root, and dead material and of inflorescence, leaf lamina, and leaf petiole $\ldots \ldots \ldots \ldots \ldots \ldots \ldots \ldots \ldots$

Figure 7. Total nonstructural carbohydrate tissue concentrations of stolon, stembase, root, and dead material and of inflorescence, leaf lamina, and leaf petiole

Figure 8. Free sugar mass per unit area of plant mass of total live mass, root, and dead material and of stolon, stembase, inflorescence, leaf lamina, and leaf petiole

Figure 9. Plant part percent of total free sugar mass for living plant material, and dead material free sugar mass as a percent of total live mass free sugar ............

Figure 10. Starch mass per unit area of plant mass of total live mass, root, and dead material and of stolon, stembase, inflorescence, leaf lamina, and leaf petiole . . . . . . . . .

Figure 11. Plant part percent of total starch mass for living plant material, and dead material starch mass as a percent of total live plant starch mass . . . . . . . . . . . .

Figure 12. Total nonstructural carbohydrate mass per unit area of plant mass of total live mass, root, and dead material and of stolon, stembase, inflorescence, leaf lamina, and

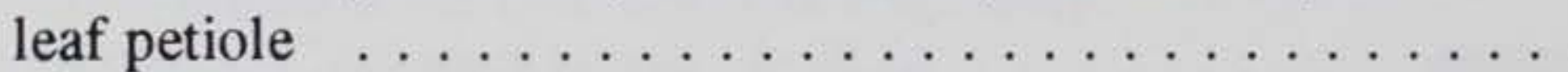

Figure 13. Plant part percent of TNC mass for living plant material, and dead material TNC mass as a percent of total live mass TNC content ................. 2

Figure 14. Total plant content of free sugar, starch, and TNC, and free sugar content as a percent of TNC 


\section{Preface}

The work reported herein was conducted as part of the Aquatic Plant Control Research Program (APCRP), Work Unit 32441. The APCRP is sponsored by the Headquarters, U.S. Army Corps of Engineers (HQUSACE), and is assigned to the U.S. Army Engineer Waterways Experiment Station (WES) under the purview of the Environmental Laboratory (EL). Funding was provided under Department of the Army Appropriation No. 96X3122, Construction General. The APCRP is managed under the Environmental Resources Research and Assistance Programs (ERRAP), Mr. J. L. Decell, Manager. Mr. Robert C. Gunkel was Assistant Manager, ERRAP, for the APCRP. Technical Monitor during this study was Mr. James Wolcott, HQUSACE.

The Principal Investigator for this work unit was Dr. Kurt D. Getsinger, Aquatic Processes and Effects Group (APEG), Ecosystem Research and Simulation Division (ERSD), EL. The study was conducted and the report prepared by Drs. John D. Madsen, Kien T. Luu, and Kurt D. Getsinger, APEG. Dr. Luu was employed by WES under an Interagency Personnel Act agreement with the University of Tennessee and, later, as a contractor through the AScI Corporation. Technical reviews of this report were provided by Drs. R. Michael Smart and Susan L. Sprecher, APEG. Technical assistance was provided by Ms. L. Nelson, Ms. S. Burt, Ms. R. Westover, Mr. J. Snow, and Ms. T. Hancock of the APEG.

This investigation was performed under the general supervision of Dr. John Harrison, Director, EL; Mr. Donald L. Robey, Chief, ERSD; and Dr. Richard E. Price, Chief, APEG.

At the time of publication of this report, Director of WES was Dr. Robert W. Whalin. Commander was COL Leonard G. Hassell, EN.

This report should be cited as follows:

Madsen, John D., Luu, Kien T., and Getsinger, Kurt D. 1993. Allocation of biomass and carbohydrates in waterhyacinth (Eichhornia crassipes): Pond-scale verification. Technical Report A-93-3, Vicksburg, MS:

U.S. Army Engineer Waterways Experiment Station. 


\section{Introduction}

\section{Background}

\section{Allocation strategies}

The allocation of resources by plants involves strategies developed in their native environment through natural selection of adaptive traits or tactics. The majority of carbon fixed from the atmosphere via photosynthesis in excess of respiratory needs is allocated to structural carbohydrates (e.g., cellulose, lignin) that make up the bulk of plant biomass. These structural building blocks may be used for nutrient acquisition (roots), light acquisition (leaf laminae), height to confer competitive advantage for light interception (petioles, stems), food storage (tubers, stembases), and propagation (inflorescences, vegetative propagules) (Madsen 1991). In addition, the plant forms nonstructural carbohydrates, carbon molecules whose sole purpose is the storage and transport of energy within the plant. Generally, glucose is the initial molecule formed, but a multitude of other free sugars may follow. These are predominantly for transport throughout the plant, and follow a path from the site of production ("source") to the ultimate area of storage or use ("sink").

A high allocation rate of carbohydrate to storage is typical of herbaceous perennial plants in the temperate zone. These plants typically form small dormant structures that are high in starch, resistant to cold, and provide a source of energy for rapid growth in the spring. Tropical and subtropical plants need not develop dormant propagules for perennation. These plants remain green throughout the year, storing only sufficient carbohydrates to overcome disturbance or transient periods of stress. Although their primary strategy for success is to remain green throughout the year and increase allocation to leaf tissue for photosynthesis, these plants also "hedge their bets" (Fitter 1986) by storing some carbohydrates to allow for regrowth after minor disturbances, herbivory, and inclement weather. This strategy may involve forming a vegetative storage organ, such as the stembase of waterhyacinth.

The primary purpose of various allocation patterns is to best invest income (carbohydrates) into storage, growth, or reproduction so as to maximize reproductive success through the production of the most offspring. This may involve allocating to long life at a low rate of reproduction, and dominating a 
site for many years; or the allocation of all plant reserves into reproduction in a single year, at the cost of the parent plant; or many strategies in between. No single tactic is optimal under all conditions, nor is a given tactic followed to the exclusion of other possible outcomes. Plant populations diversify their chances for survival (e.g., "hedge their bets") by investing the major proportion of energy into the most generally effective form of growth or highprobability strategy, while putting a minor allocation into an alternative strategy to protect against the unexpected, or low-probability, occurrence such as major disturbances and catastrophic events (Fitter 1986).

\section{Carbohydrates}

Plant carbohydrates are typically described in three forms: free sugars, starch, and structural carbohydrates. Free sugars are relatively small molecules that are the form in which reduced carbon is used by cells for energy (e.g., reducing sugars) or transported throughout the plant (e.g., nonreducing sugars). The most common free sugar molecules include glucose, sucrose, and fructose, though other forms occur. In addition to their transportability, free sugars are readily consumed by cells in respiration and are the energy currency of the plant. However, the cell is limited in the amount of soluble sugar that can be stored.

Insoluble starch is the long-term storage carbohydrate in the plant that can be readily reconverted to sugars. Large quantities (up to 40 percent dry weight of the plant part) can accumulate in various tissues. However, starch cannot be translocated outside the cell or through the plant, since it is a large molecule.

Total nonstructural carbohydrates (TNC) is the term used for the sum of these two nonstructural components (free sugars and starch), and indicates the amount of food/energy reserves in the plant. Other carbohydrates, such as cellulose, which makes up cell walls, are structural in nature and are unavailable as food.

TNC by itself provides a great deal of information about the status of plant reserves in various plant parts. For this reason, many publications present TNC without breaking it down into starch and free sugar components. However, differentiation between these two components of TNC provides additional information, such as the amount of immediately translocatable carbohydrates, or the quantity of starch reserves available to aid recovery from stress, herbivory, or disturbance.

\section{Waterhyacinth Biology and Management}

Waterhyacinth (Eichhornia crassipes (Mart.) Solms) is a worldwide nuisance-forming aquatic plant, creating obstructive floating mats in tropical 
and subtropical waterways on every continent including its native South America (Holm 1969, Holm et al. 1977). In 1977, at the plant's greatest extent, more than 16,000 ha of waterhyacinth were growing in Florida lakes (Schardt 1990). Waterhyacinth also forms nuisance populations in the other Gulf Coast States and in California.

Waterhyacinth is perennial, forming floating rosettes buoyed by bladders in the petioles of the leaves. As the stand matures, bladders are no longer formed, and the mass of the mat itself maintains buoyancy. The roots may take nutrients from the water column or, in shallower water, root into the sediment. Although prodigious numbers of seeds are formed and flowering is common, vegetative propagation predominates throughout waterhyacinth's tropical and subtropical range. New daughter plants are formed at the end of stolons by mature rosettes. Many generations of plants, vegetatively formed, can be connected by stolons and support each other by mutual exchange of carbohydrates and nutrients. In addition, plants may regrow from the stembase after a mild frost, herbivory, or sublethal herbicide treatment. However, the plant cannot withstand a hard freeze. Therefore, its range is strictly tropical and subtropical, although some populations survive beyond this range, through continued introduction, persistent vegetative parts, or regeneration from the seed bank (Westover and Madsen 1992).

A typical life cycle for waterhyacinth in subtropical Florida is exemplified by a study reported by Center and Spencer (1981). Biomass is lowest in January, when much of the leaf material is sloughed as the result of low, but not necessarily freezing, temperatures. As temperatures warm in March, biomass increases to a peak in early June and then recedes to a constant lower value throughout the summer and fall, until a winter decline begins in November, lasting through February. Green leaves may or may not be found throughout this period; plants tend to die back to either the stembase or to prostrate floating leaves.

At the northern edge of waterhyacinth's range, such as might be found in eastern Texas, waterhyacinth typically loses all above-water structures as the result of freezing temperatures, sometime between October and December. In some years, winter temperatures are sufficiently mild to allow stembases to overwinter, from which leaves grow in April. In other years, cold temperatures are sufficient to kill even the submersed stembases, and populations may regrow from a dormant seed bank, beginning in March or April. Maximum biomass is reached in July and persists until the first frost of October or November.

\section{Application of Phenology to Management}

Management of nuisance aquatic plants has often been based on trial and error alone, without any theoretical, biological, or mechanistic basis for making management decisions or for understanding the biological factors affecting 
control success or failure (Nichols 1991). A biological basis for our management decisions is required:

All control techniques stress the plant. In the past, the timing of control efforts was often based on the demands of the user, not on the life cycle of offending species. To increase the efficacy of control, stress must be maximized. Research that concentrates on resource accumulation and allocation for nuisance plants under a variety of conditions is needed so that treatments can be timed to stress species when they are physiologically most vulnerable. This may be at a point when their energy reserves are low, when they are most receptive to the uptake of chemicals, or at some other critical point in their life cycle. Easily recognizable indicators of physiological status are needed to properly time management efforts (Nichols 1991, p 245).

This quote succinctly summarizes the purpose and goals of the Aquatic Plant Control Research Program's Phenology Work Unit, which couples knowledge of the physiological state of the plant and visible indicators of plant status with environmental indicators to define susceptible points in the life cycle for application of management techniques, to optimize control of the target species.

This approach has been used for only a few other weedy species, but currently is not widely practiced. Linde, Janisch, and Smith (1976) studied the phenology and carbohydrate status of cattail (Typha angustifolia L.) to determine the best time for control efforts. By coupling carbohydrate status with other common phenological parameters, they determined that optimum control could be most easily achieved during anthesis, when flowers were in full development. The application of phenological studies to elucidate weak points in aquatic plant life cycles was recently discussed by Pesacreta and Luu (1988). The myriad of possible factors to assess indicated the need for a single parameter that would indicate the overall status of a plant. Carbohydrate partitioning, particularly the content of TNC, had been shown to track the ability of Eurasian watermilfoil (Myriophyllum spicatum L.) to recover after harvesting (Kimbel and Carpenter 1981).

Based on these and other studies, further analysis of TNC as an indicator of a plant population's ability to recover from management efforts was undertaken by Luu and Getsinger (1988; 1990a,b). Small-scale application of phenological analysis of waterhyacinth, including measurement of carbohydrate status, substantiated the hypotheses of the feasibility study. Low TNC levels were found at two periods: early in the growing season before plants reach considerable size, and in early fall when plants begin to allocate carbohydrates to the stembase for overwintering (Luu and Getsinger 1988; 1990a,b). 


\section{Objectives}

The objectives of this current research effort were to

a. Evaluate and compare the observations of earlier short-term, smallscale studies with studies conducted in ponds over a complete growing season.

b. Elucidate carbohydrate and biomass allocation patterns in waterhyacinth, and determine times and techniques to maximize control efforts. 


\section{Methods}

\section{Meteorological Monitoring}

Air temperature at the U.S. Army Engineer Waterways Experiment Station (WES) Lewisville Aquatic Ecosystem Research Facility (LAERF) in Lewisville, TX (latitude $33^{\circ} 04^{\prime} 45^{\prime \prime} \mathrm{N}$, longitude $96^{\circ} 57^{\prime} 30^{\prime \prime} \mathrm{W}$ ) was monitored continuously using an Omnidata EasyLogger and thermistor, with air temperatures scanned every 5 min and averaged each hour. Each day, the minimum and maximum scanned values, as well as hourly averages, were stored for later output (Figure 1).

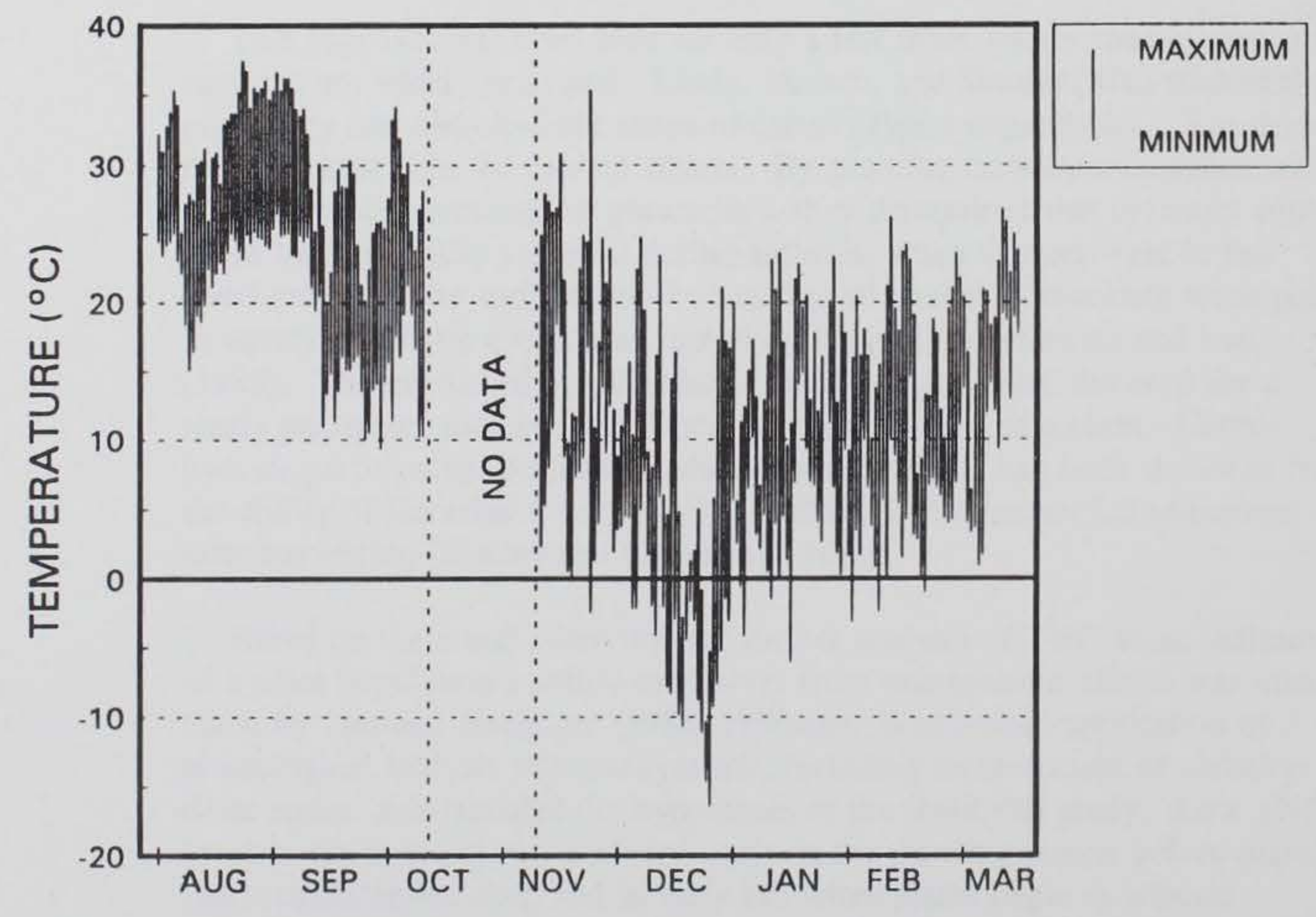

Figure 1. Maximum and minimum air temperature $\left({ }^{\circ} \mathrm{C}\right)$, Lewisville Aquatic Ecosystem Research Facility, August 1989-March 1990 


\section{Plant Sampling and Carbohydrate Analysis}

Waterhyacinth plants, overwintered in a greenhouse, were planted in a 0.3-ha pond at the LAERF in May 1989. Samples were taken every month from June 1989 through March 1990 using a $0.25-\mathrm{m}^{2}$ quadrat frame, with all plants within the quadrat removed for analysis. Five replicate samples were taken, by placing the quadrats randomly within the waterhyacinth mat. Plants were separated into young (i.e., the first two, or innermost, leaves) petioles, young leaf laminae, mature (i.e., the balance of leaves) petioles, mature leaf laminae, old (i.e., the last two, or outermost leaves) petioles, old leaf laminae, leaf membranes, inflorescences, stolons, stembases, roots, and dead material for each sample (Figure 2). Samples were dried in a forced-air oven at $55^{\circ} \mathrm{C}$, for at least $48 \mathrm{hr}$, to a constant dry weight. Samples were weighed, then ground using a Cyclone Sample Mill (Udy Corporation, Boulder, CO), to pass through a $1-\mathrm{mm}$ screen.

Plant samples were analyzed for TNC using a modification of the method by Swank et al. (1982). Extracts of TNC (starch, hydrolyzable sugars, reducing sugars) were incubated for $15 \mathrm{~min}$ at $55^{\circ} \mathrm{C}$ with one unit of amyloglucosidase (Sigma A-3042) per milliliter to completely hydrolyze starch before assaying for reducing sugars (Nelson 1944). Free sugars were determined on extracts not incubated with amyloglucosidase.

The percent distribution of dry weight for plant parts was calculated based on the sum of all parts except dead material. Leaf lamina weight was calculated as the sum of young lamina, mature lamina, and old lamina. Leaf petiole weight was calculated using the sum of young petiole, mature petiole, old petiole, and membrane weight. The concentrations of carbohydrates are presented as grams per $100 \mathrm{~g}$ dry weight, or percent dry weight. The mass balance of carbohydrates was calculated by multiplying the biomass of each component plant part times the concentration of free sugar, starch, or TNC. 


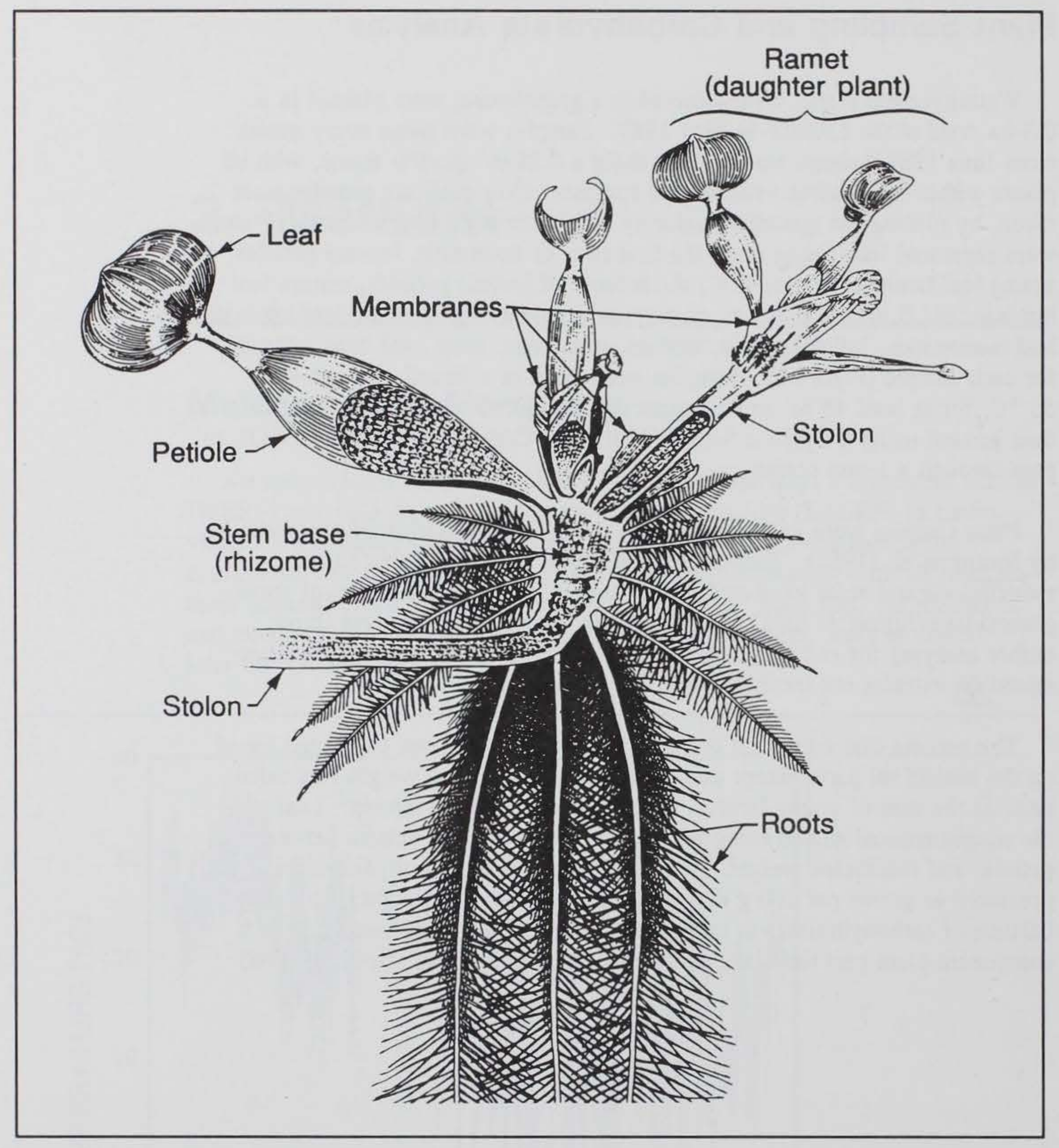

Figure 2. Major vegetative parts of waterhyacinth 


\section{Results and Discussion}

\section{Meteorological Data}

Daily minimum and maximum air temperatures are presented in Figure 1. Data are missing for the period 10 October to 8 November because of an equipment failure. The important information is that light frosts were observed repeatedly from mid-November through late February, but killing freezes occurred only in mid- to late-December. During this December sampling period, plant materials was extracted from the frozen pond for analysis.

\section{Seasonal Biomass Distribution}

In general, above-water plant mass peaked in the fall, with roots and stembases accounting for the majority after frost-kill. Total plant biomass at the first sampling period in June was $640 \mathrm{~g} \mathrm{~m}^{-2}$, but rapidly grew to approximately $1,100 \mathrm{~g} \mathrm{~m}^{-2}$ in July and maintained that biomass level through November (Figure 3a). After a substantial frost in December, biomass decreased to a final low of $550 \mathrm{~g} \mathrm{~m}^{-2}$ in March. Root biomass rose from an initial 260 to a peak of $920 \mathrm{~g} \mathrm{~m}^{-2}$ in November. Leaf biomass followed with a peak total (including lamina, petiole, and membrane) of almost $620 \mathrm{~g} \mathrm{~m}^{-2}$, of which 140 to $190 \mathrm{~g} \mathrm{~m}^{-2}$ was leaf lamina (Figures 3a,b). Stembases ranged from 24 to $73 \mathrm{~g} \mathrm{~m}^{-2}$, as did inflorescences. Stolons remained at a relatively low biomass level of approximately $20 \mathrm{~g} \mathrm{~m}^{-2}$. Only stembases and roots, the underwater parts of the plant, survived after a December freeze. All other tissues died rapidly, resulting in a major proportion of dead material in December to March samplings.

The previous small-scale study conducted at WES (Luu and Getsinger $1990 \mathrm{a}, \mathrm{b}$ ) had a maximum waterhyacinth total biomass of $800 \mathrm{~g} \mathrm{~m}^{-2}$ (less than the pond study), which peaked in September and rapidly declined in the following months. The LAERF maximum total biomass of $1,100 \mathrm{~g} \mathrm{~m}^{-2}$ was less than the waterhyacinth peak biomass found in a north-central Florida lake in early summer $\left(2,500 \mathrm{~g} \mathrm{~m}^{-2}\right.$; Center and Spencer 1981), but approached the typical summer and fall biomass of $1,600 \mathrm{~g} \mathrm{~m}^{-2}$ observed for the same lake. However, the growing season and longevity of maximum biomass were less at LAERF than observed in north-central Florida. Total biomass for 


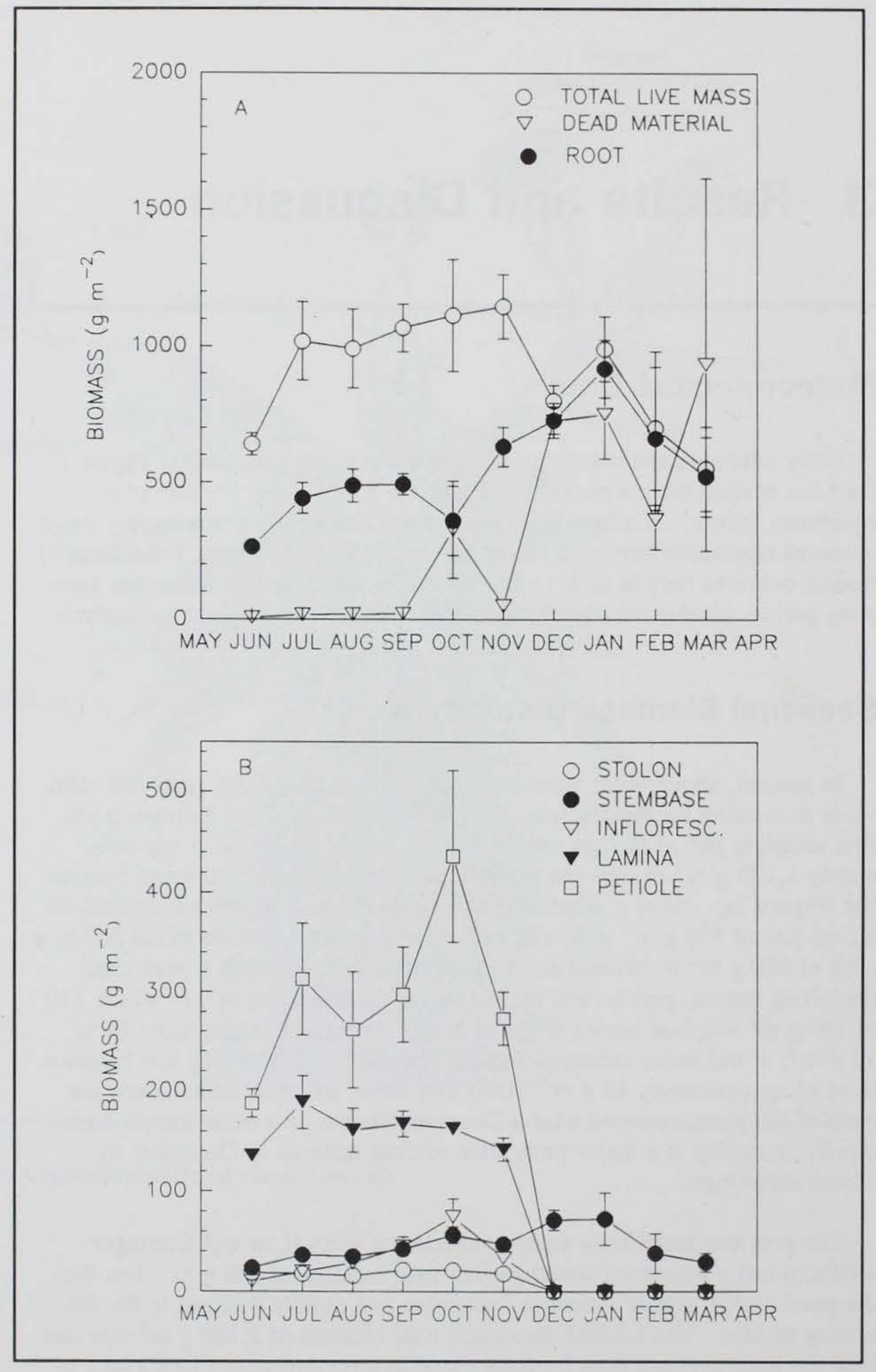

Figure 3. Biomass ( $g$ dry weight $\mathrm{m}^{-2}$ ) of the sum of live mass, dead material, and root (A) and of the stolon, stembase, inflorescence, leaf lamina, and leaf petiole (B). Bar indicates \pm 1 standard error of the mean 
waterhyacinth populations near New Orleans ranged from 2,000 to 2,500 (Penfound and Earle 1948). Although the LAERF pond is located near the northern range of waterhyacinth, biomass values achieved in this young population in the pond are somewhat comparable to those observed in other natural environments.

Stembases, stolons, and inflorescences were minor components of total biomass, each contributing less than 10 percent to total biomass at any one time, which is largely consistent with the small-scale study (Figure 4a). This amount indicates a small contribution to vegetative and sexual propagation, since inflorescences (producing seed), stolons (contributing to vegetative propagation), and stembases (overwintering and regrowth) are all involved in propagation. Aquatic plants that are annuals may dedicate over 30 percent of biomass to sexual propagation, whereas herbaceous perennials, which completely die back over the winter as part of their natural strategy, typically contribute 25 percent or more of biomass to vegetative propagation (Madsen 1991). For temperate-zone plants, perennation is a vital consideration that calls for a significant contribution of resources, whether in seed production or vegetative propagule production. Perennial forms such as waterhyacinth, which do not die back, generally contribute less to propagation, since their partitioning strategy calls for a strong vegetatively mature plant.

During the growing season, root biomass comprised 30 to 55 percent of total biomass (Figure 4a), and total leaf mass was 35 to 50 percent of total biomass, with approximately 65 percent of the leaf mass being in petioles and the rest in leaf lamina. These values are consistent with the results from the WES waterhyacinth outdoor tank studies (Luu and Getsinger 1990b). After the killing frost in December, plant mass was 90 percent root and the remainder stembase (Figure 4a). During the active growing season, dead material was a small proportion of total living material. A mild frost in October (not shown in Figure 1) caused an increase in dead material, but the population recovered vegetatively. The freeze in December caused substantial mortality, with 50 percent of all tissue dying immediately and the remainder decreasing over an extended period of time (Figures $4 a, b$ ).

\section{Carbohydrate Concentration}

\section{Free sugar}

Free sugar levels, which indicate the translocation of energy reserves and are also related to active growth, remained high in most tissues until growth was terminated by freezing temperatures. The concentration of free sugar in the roots and dead material remained consistently low at 3 to 4 percent over the course of the study (Figure 5a). Roots of waterhyacinth are an actively respiring tissue and have no adaptations for carbohydrate storage; therefore, carbohydrates should not accumulate in these tissues. In contrast, the level of sugars in both stolons and stembases increased throughout the growing season, reaching 10 percent in stolons (November) and 16 percent in stembases 

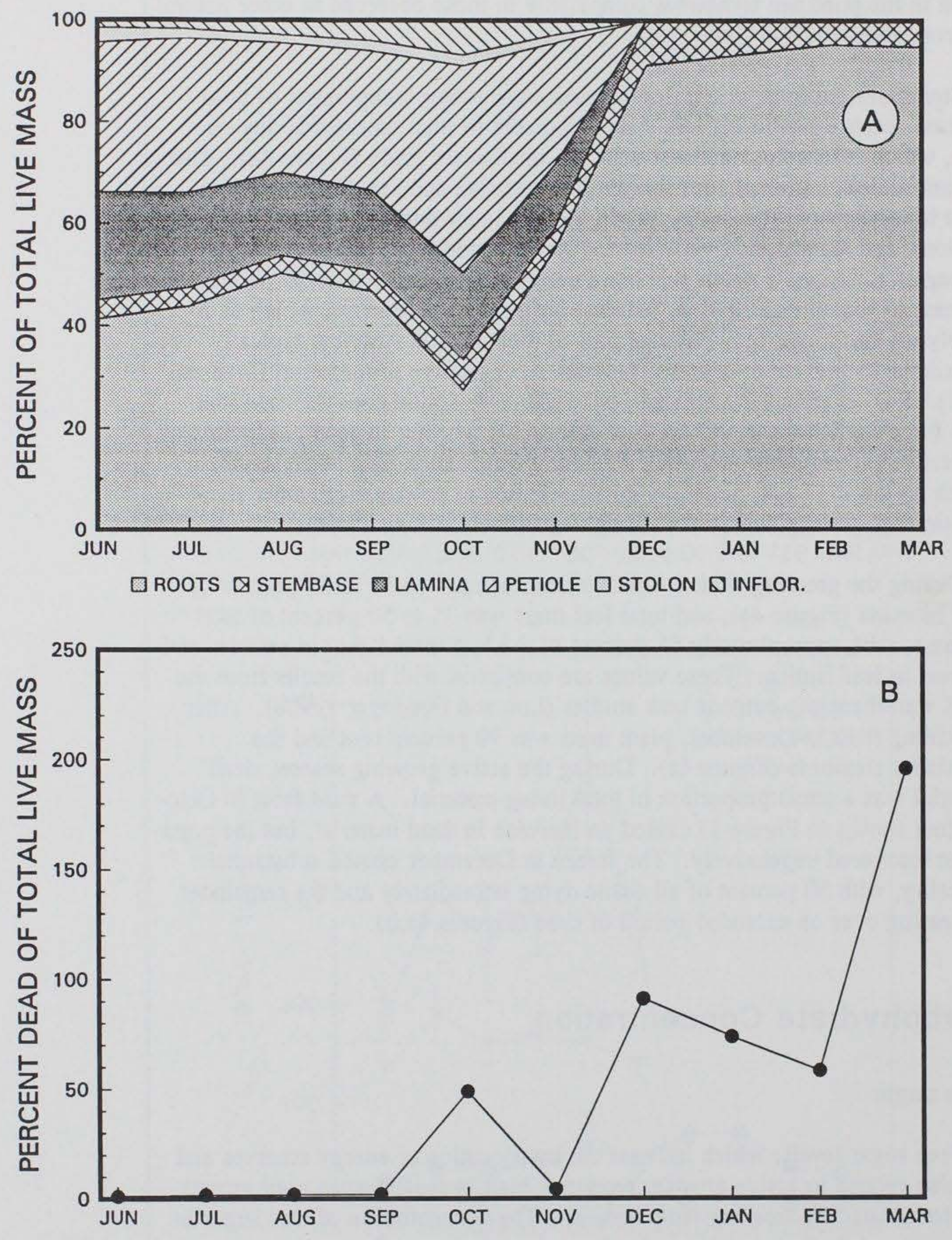

Figure 4. Partitioning of biomass into component parts of waterhyacinth as a percentage of living mass $(A)$ and dead material mass as a percentage of total live mass (B) 

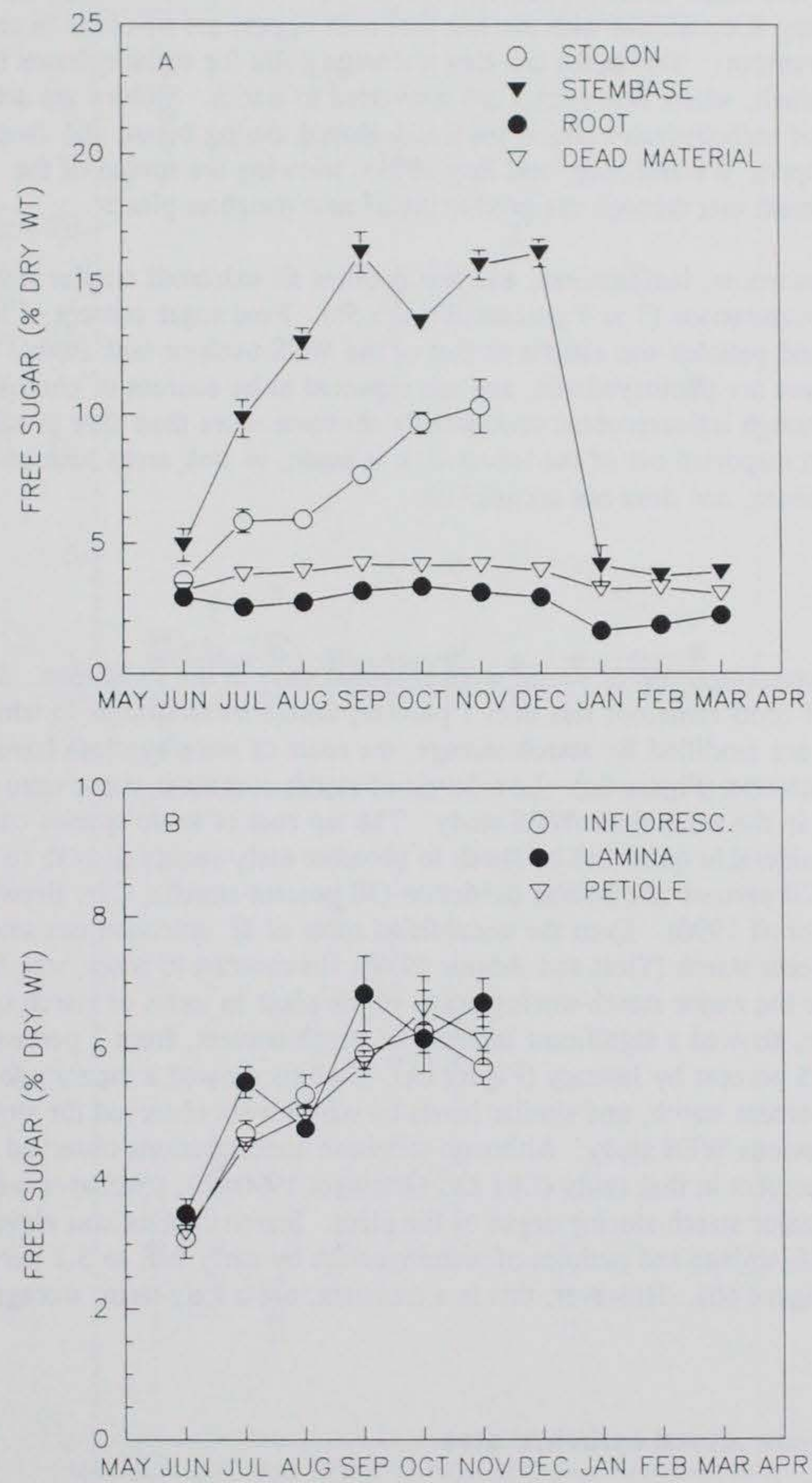

Figure 5. Free sugar tissue concentrations (percent dry weight) of stolon, stembase, roots, and dead material (A) and of inflorescence, leaf lamina, and leaf petiole $(B)$. Bar indicates \pm 1 standard error of the mean 
(December). These results are similar to those in the WES small-scale study, in which free sugar content peaked in fall for both stolons and stembases.

This finding is consistent with the fact that both organs are involved in carbohydrate transport. Stembases are also a storage point for carbohydrates in waterhyacinth, where free sugars are converted to starch. Stolons are active conduits of carbohydrates which are freely shared among parent and daughter plants (Alpert, Warembourg, and Roy 1991), allowing the spread of the waterhyacinth mat through the production of new daughter plants.

Inflorescences, leaf laminae, and leaf petioles all exhibited similar free sugar concentrations ( 3 to 7 percent, Figure $5 b$ ). Free sugar content of leaf laminae and petioles was similar to that of the WES outdoor tank study. All three tissues are photosynthetic, and are expected to be sources of photosynthate, although inflorescences undoubtedly consume more than they produce. Sugar is transported out of the leaves as it is made, to sink areas such as inflorescences, and does not accumulate.

\section{Starch}

High concentrations of starch were observed only in the stembases. Starch content of roots remained less than 1 percent; unlike some species in which the roots are modified for starch storage, the roots of waterhyacinth have no storage function (Figure 6a). Low levels of starch content in roots were also observed in the small-scale WES study. The tap root of some species can store considerable quantities of starch to promote early-season growth (e.g., chicory (20 percent starch) and dandelion (30 percent starch); Cyr, Brewley, and Dumbroff 1990). Even the unmodified roots of $M$. spicatum can store up to 20 percent starch (Titus and Adams 1979). In contrast to roots, stembases, which are the major starch-storing organ of the plant in terms of starch concentration, showed a significant increase in starch content, from 1 percent in June to 25 percent by January (Figure 6a). Stolons showed a capacity to store up to 5 percent starch, and similar levels of starch were observed for stolons in the previous WES study. Although stembase concentrations observed were only 12 percent in that study (Luu and Getsinger 1990a,b), stembases were still the major starch-storing organ of the plant. Starch content was elevated in the leaf laminae and petioles of waterhyacinth by early fall, to 3.2 percent starch (Figure 6b). However, this is a transient, not a long-term, storage function.

\section{Total nonstructural carbohydrates}

Levels of TNC followed similar patterns to those observed for free sugar and starch. In root material, TNC, which is the sum of both starch and free sugars, remained relatively constant (Figure 7a). Stolon TNC content increased from 5 to 15 percent before senescence, primarily because of an increase in free sugar. Similar results in the WES small-scale study prompted speculation that stolons may also have a carbohydrate-storage function, 

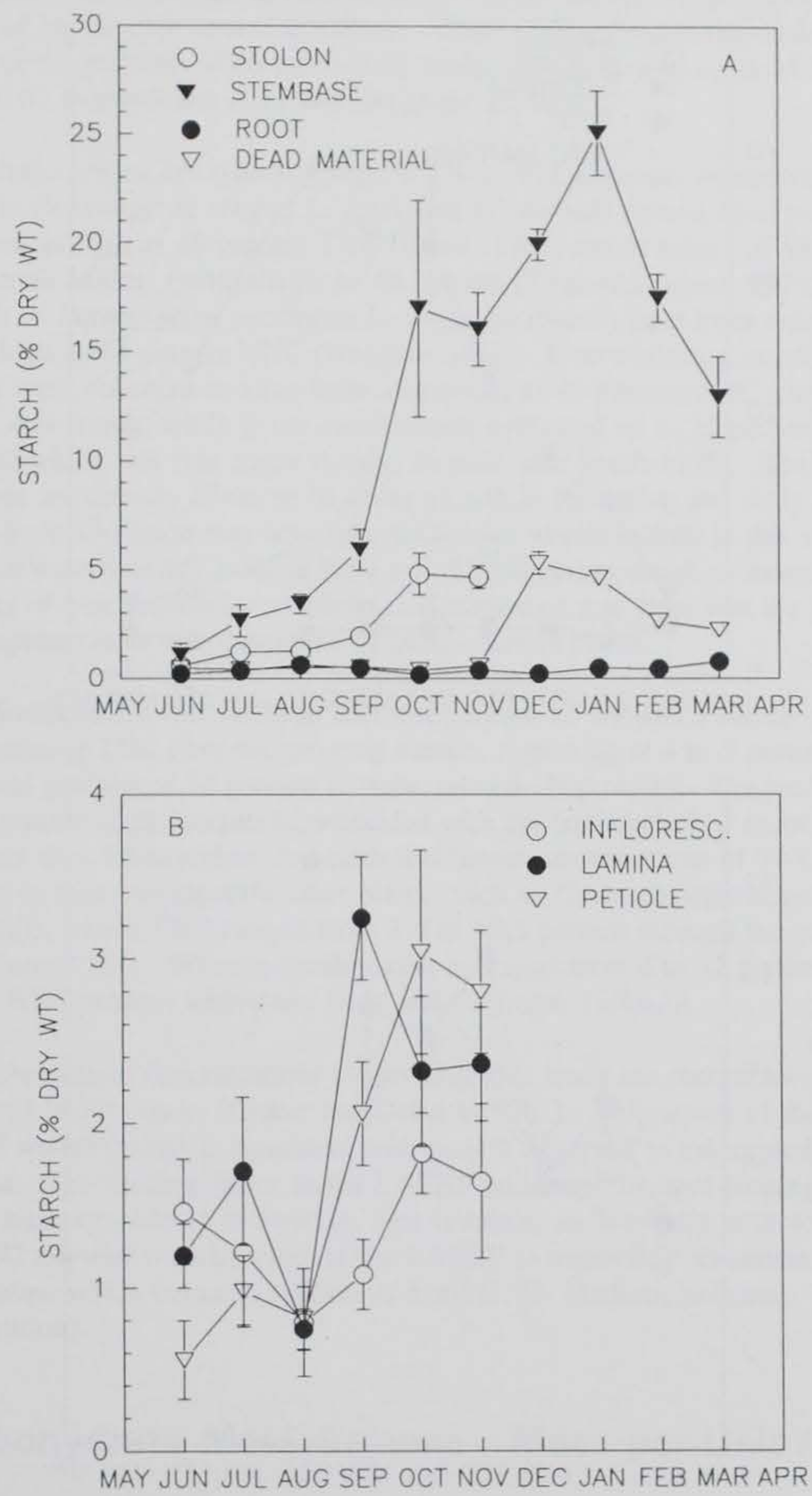

Figure 6. Starch tissue concentrations (percent dry weight) of stolon, stembase, root, and dead material $(A)$ and of inflorescence, leaf lamina, and leaf petiole $(B)$. Bar indicates \pm 1 standard error of the mean 

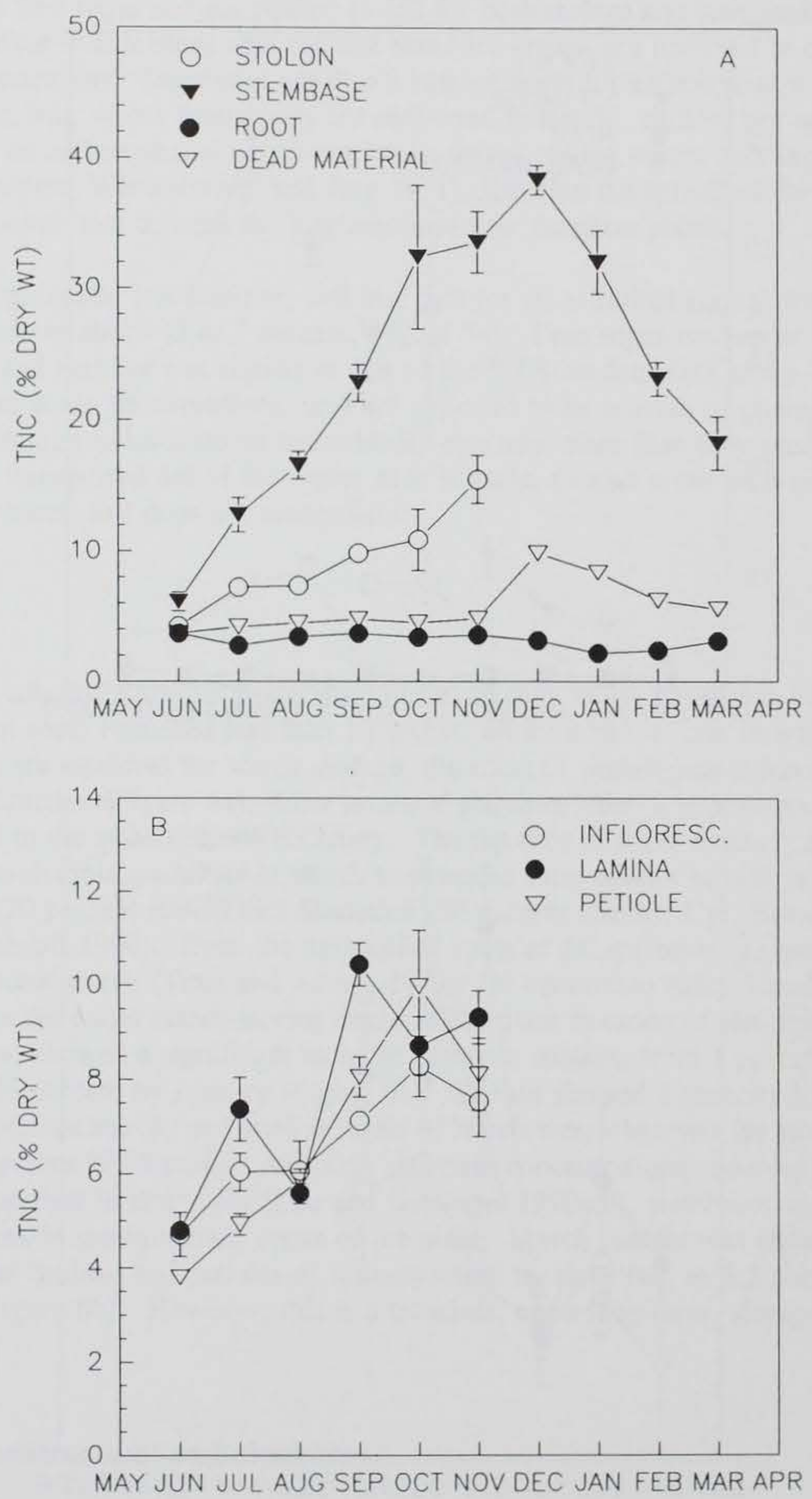

Figure 7. Total nonstructural carbohydrate tissue concentrations (percent dry weight) of stolon, stembase, root, and dead material (A) and of inflorescence, leaf lamina, and leaf petiole (B). Bar indicates \pm 1 standard error of the mean 
secondary to that of the stembase. In comparison, stembase material increased from 5 percent in June to 40 percent in December, primarily as the result of an increase in starch content. These findings were comparable to those of the previous WES small-scale study, which showed up to 31.5 percent TNC in stembases (Luu and Getsinger 1990a,b).

Storage organs are typically high in TNC. For instance, concentrations of TNC in Potamogeton crispus L. (curlyleaf pondweed) turions have been reported as high as 40 percent TNC (Kunii 1989), and in tubers of Vallisneria americana Michx. (wildcelery), to 48 percent (Titus and Adams 1979). Tubers of Potamogeton pectinatus L. (sago pondweed) have been reported to be as high as 74 percent TNC (Hodgson 1966). Overwintering cattail rhizomes were observed to have from 35 percent to 45 percent TNC, most of which was starch, while green aerial shoots contained up to 15 percent TNC, most of which was free sugar (Linde, Janisch, and Smith 1976). These reserves are directly allocated to shoot growth in the spring and early summer. Such allocation was not observed for the waterhyacinth in this study because waterhyacinth rosettes were not planted early enough to monitor the subsidy of new growth by stembases. However, it was clear that the growth of daughter plants was supported by older, mature plants.

Inflorescences, leaf laminae, and leaf petioles all showed a similar pattern of increasing TNC over the growing season, beginning at 4 to 5 percent in June and peaking at 10 percent in early autumn (Figure $7 \mathrm{~b}$ ). The peak in TNC content of dead material coincided with the fresh influx of shoot material that was frost-killed. Waterhyacinth leaf tissue concentrations of TNC were similar to those observed in other plants, such as Ceratophyllum demersum L. (coontail), where TNC ranged from 3.4 to 10.5 percent through the year (Best and Visser 1987). Waterhyacinth leaves averaged from 4 to 12 percent TNC in the WES outdoor tank study (Luu and Getsinger 1990a,b).

Carbohydrate concentrations observed in this study are comparable to those observed in Florida by Tucker and DeBusk (1981). This aspect of the phenology of waterhyacinth is consistent with growth observed in subtropical Florida. The limiting factor in the LAERF pond was the hard freeze, which killed waterhyacinth in midwinter. For instance, an unusually mild winter in 1991-92 allowed waterhyacinth at the LAERF to overwinter as submersed stembases, which began to regrow in April (J. D. Madsen, personal observation).

\section{Carbohydrate Mass Balance - Mass per Unit Area}

Most studies analyzing carbohydrate data, or tissue nutrient data, report only on the concentration of these components in various plant parts. Further information on the contribution of component parts to the total balance of carbohydrates or tissue nutrients in the plant can be gained by calculating the mass balance. A mass balance of carbohydrates, for instance, can be found by multiplying the concentration of the carbohydrate by the weight of the 
component parts and summing these weights for total plant carbohydrate. It may be more desirable to make these calculations based on the weight per unit area, or biomass, of the plant population rather than on an individual plant in order to examine the population as a whole. In waterhyacinth, these calculations reveal the contribution of component organs to the overall carbohydrate production of the population, and emphasize the increase in carbohydrate production during the growing season.

Using mass balance calculations, it is evident that the population tripled total free sugar content in one growing season. Total free sugar mass of all plant materials started at $20 \mathrm{~g} \mathrm{~m}^{-2}$ and peaked at $63 \mathrm{~g} \mathrm{~m}^{-2}$ (Figure 8a).

Although root material is low in free sugar, the total mass of free sugar in roots ranged from 7 to $21 \mathrm{~g} \mathrm{~m}^{-2}$. Free sugar mass in leaf petioles increased dramatically throughout the growing season, peaking at $32 \mathrm{~g} \mathrm{~m}^{-2}$, higher than all other tissues. When combined with the $12 \mathrm{~g} \mathrm{~m}^{-2}$ in leaf laminae, the total for leaves $\left(44 \mathrm{~g} \mathrm{~m}^{-2}\right)$ far exceeds other tissues. Since leaves are the source of free sugar, high amounts are expected (Figure 8b). The December peak for stembases at $12 \mathrm{~g} \mathrm{~m}^{-2}$ represents a peak of translocation to these tissues. Stembases are a sink for sugars destined for conversion to starch and storage. In fact, once leaf material is killed as the result of a heavy frost, the free sugar content of stembases falls dramatically as remaining sugars are converted to starch. Inflorescences and stolons were negligible pools of free sugars.

During the growing season, 60 percent of free sugars was found in leaf material--40 percent in leaf petioles and 20 percent in leaf laminae (Figure 9a). Stembases accounted for up to 12 percent of free sugars during the growing season, and 35 percent just after the freeze in December. A large proportion of the free sugar was lost to dead material (Figure 9b), rather than being saved through translocation to stembases before the frost. Waterhyacinth, being a tropical plant, does not have the conservative physiology and allocation patterns characteristic of temperate species which prepare for low temperatures by prior storage of carbohydrates (Larcher 1980).

Total starch, like free sugars, peaked at $36 \mathrm{~g} \mathrm{~m}^{-2}$ in October, having started at $4 \mathrm{~g} \mathrm{~m}^{-2}$ (Figure 10a). A similar amount of starch was found in dead material in December, although this does not imply that all stored starch was lost. Root material was never a large pool of stored starch. In contrast, stembases reached a high of $19 \mathrm{~g} \mathrm{~m}^{-2}$ of starch in January, but contained only $10 \mathrm{~g} \mathrm{~m}^{-2}$ of starch in the growing season, when leaf petioles contained $19 \mathrm{~g} \mathrm{~m}^{-2}$ and leaf laminae another $4 \mathrm{~g} \mathrm{~m}^{-2}$ (Figure 10b). Other components stored a negligible amount of starch. The starch in the leaves may constitute an active reserve, which represents production ahead of the ability to translocate sugar. Unlike storage organs, starch concentrations in the leaf are relatively low, but the high biomass of leaves results in leaves being a large pool of starch. Starch is stored in the leaves during the day to counteract the otherwise high water potential that would result from a comparable amount of sugars in the leaves. Increased starch has been cited as useful in cold-hardening of temperate plants (Cyr, Brewley, and Dumbroff 1990), although this would be a secondary 

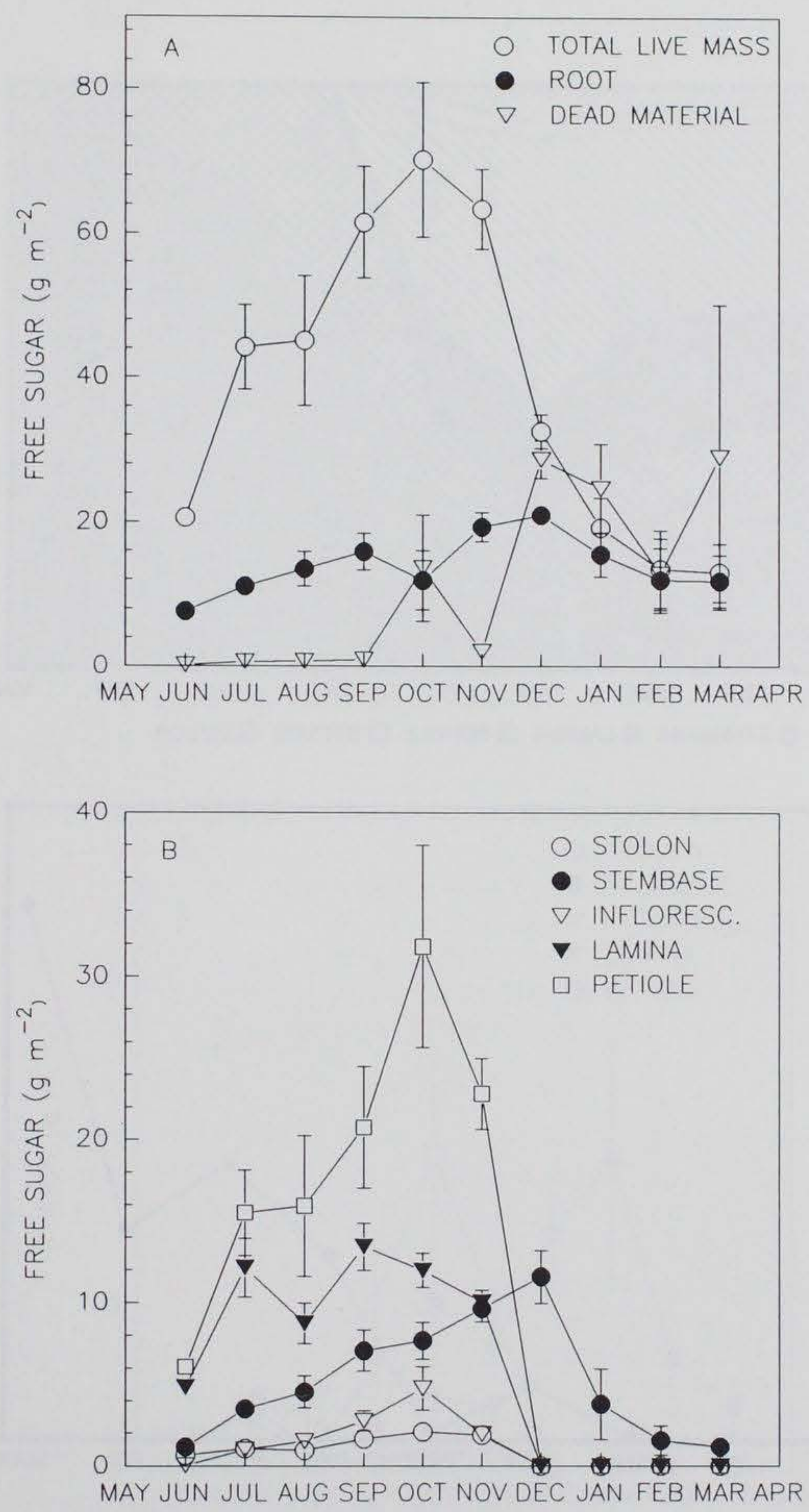

Figure 8. Free sugar mass per unit area of plant mass $\left(\mathrm{g} \mathrm{m}^{-2}\right)$ of total live mass, root, and dead material $(A)$ and of stolon, stembase, inflorescence, leaf lamina, and leaf petiole (B). Bar indicates \pm 1 standard error of the mean 


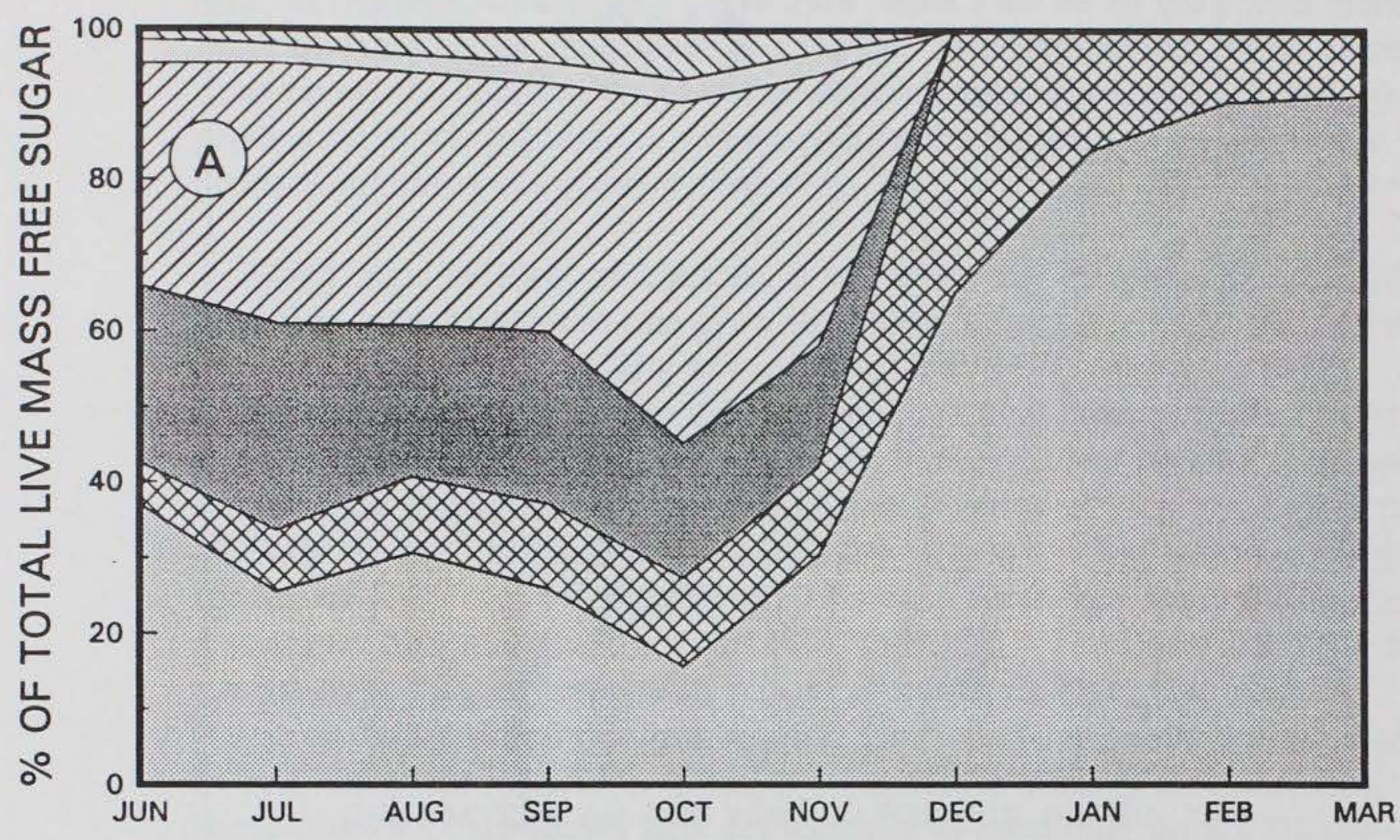

$\square$ ROOTS $\square$ STEMBASE $\square$ LAMINA $\square$ PETIOLE $\square$ STOLON $\square$ INFLOR.

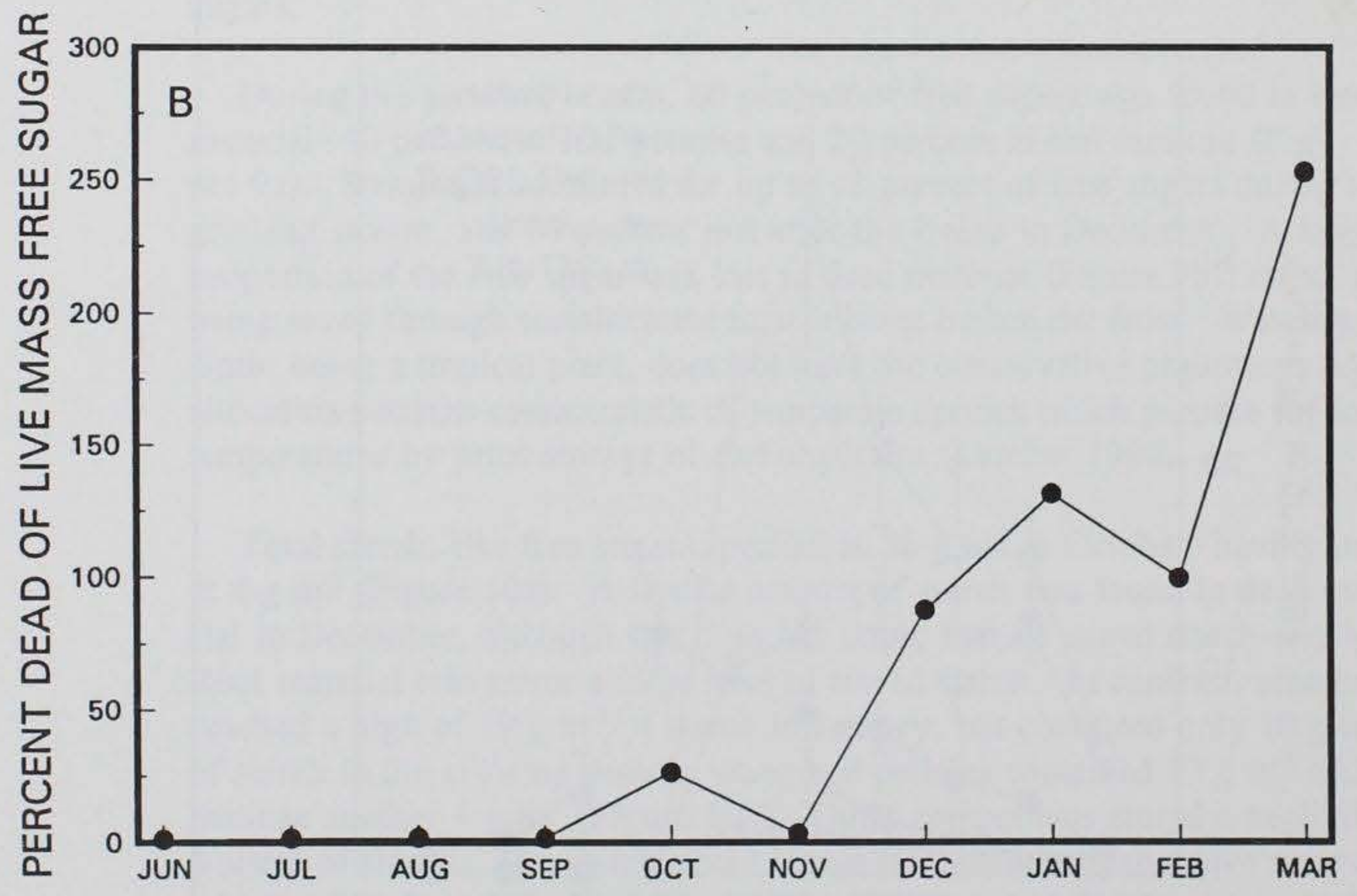

Figure 9. Plant part percent of total free sugar mass for living plant material (A) and dead material free sugar mass as a percent of total live mass free sugar (B) 

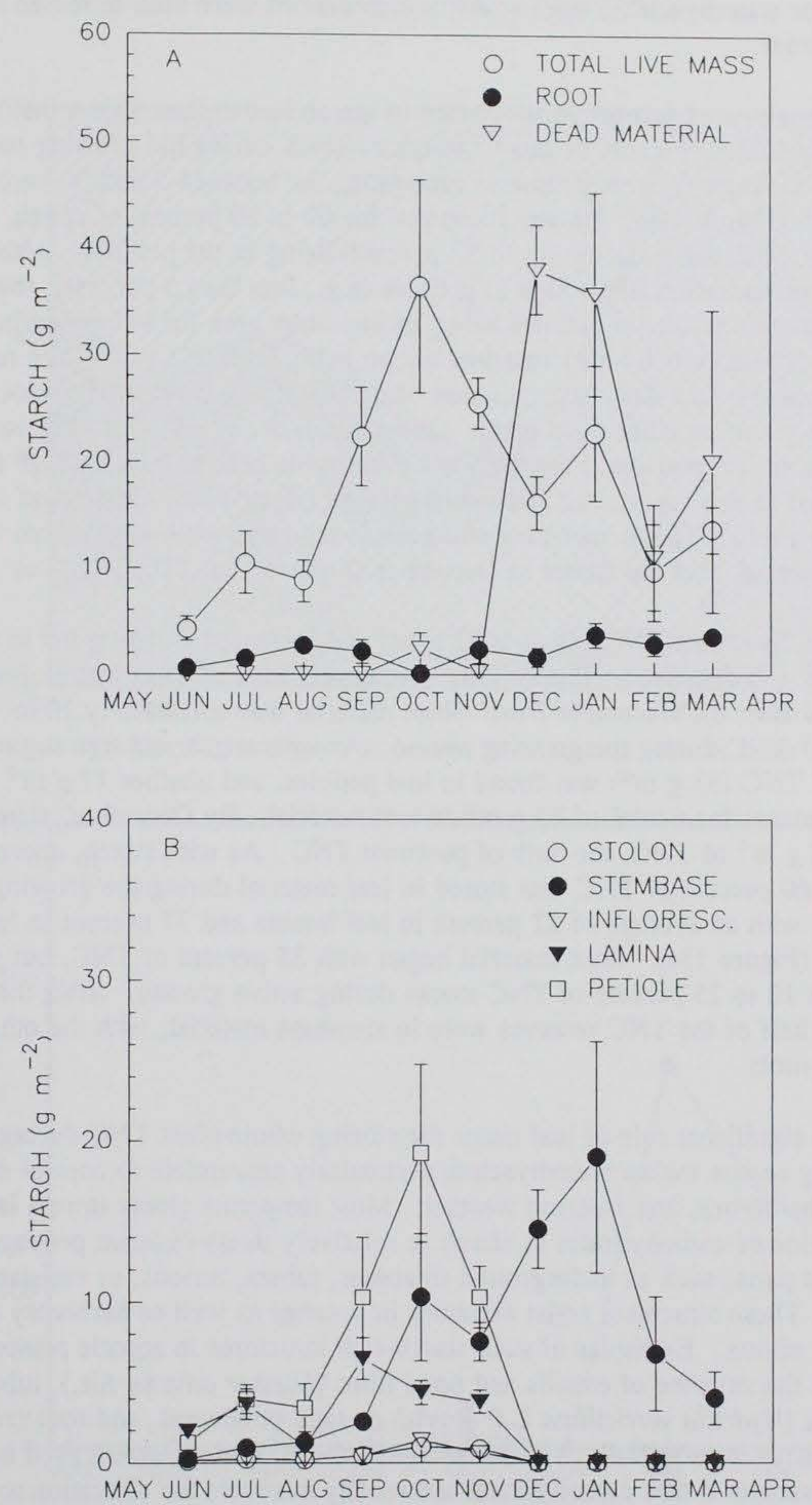

Figure 10. Starch mass per unit area of plant mass $\left(\mathrm{g} \mathrm{m}^{-2}\right)$ of total live mass, root, and dead material (A) and of stolon, stembase, inflorescence, leaf lamina, and leaf petiole (B). Bar indicates \pm 1 standard error of the mean 
effect for waterhyacinth, since starch accumulations were seen in leaves in midsummer.

An analysis of percent accumulation of starch in the plant shows that roots typically held 10 percent or less of starch reserves during the growing season (except in August), with stembases accounting for between 5 and 30 percent of starch (Figure 11a). Leaves accounted for 60 to 80 percent of starch reserves, with the majority (up to 52 percent) being in the petioles. Although starch concentration is not high in petioles (e.g., less than 5 percent), their large biomass results in petioles being an important area for storing carbohydrates. These carbohydrate reserves are probably "active"; that is, the reserve is composed of the daily accumulation of carbohydrates awaiting translocation to other plants or other plant parts. One obvious drawback to storing carbohydrates in leaf petioles is that they are susceptible both to cold damage (as discussed in this report) and herbivore damage (Haag 1986, Center and Durden 1986). The former case was seen in the large amount of starch lost in dead material after the freeze in December (Figures 10a, 11b).

Total live mass TNC began at $27 \mathrm{~g} \mathrm{~m}^{-2}$ and increased to $109 \mathrm{~g} \mathrm{~m}^{-2}$ in October, a 4.4-fold increase (Figure 12a). However, $71 \mathrm{~g} \mathrm{~m}^{-2}$ was lost to dead material after the December frost. Root material was consistently 10 to $20 \mathrm{~g} \mathrm{~m}^{-2}$ TNC during the growing season. As with starch and free sugar, the bulk of TNC $\left(53 \mathrm{~g} \mathrm{~m}^{-2}\right)$ was found in leaf petioles, and another $17 \mathrm{~g} \mathrm{~m}^{-2}$ in leaf laminae, for a total of $70 \mathrm{~g} \mathrm{~m}^{-2}$ in leaf material. By December, stembases held $28 \mathrm{~g} \mathrm{~m}^{-2}$ of TNC, the bulk of postfrost TNC. As with starch, approximately 60 percent of TNC was stored in leaf material during the growing season, with an average of 22 percent in leaf lamina and 37 percent in leaf petiole (Figure 13a). Root material began with 35 percent of TNC, but generally has 10 to 25 percent of TNC stocks during active growth. After the freeze, half of the TNC reserves were in stembase material, with the other half in roots.

The significant role of leaf tissue for storing whole-plant TNC during the growing season makes waterhyacinth particularly susceptible to control measures, herbivory, and freezing weather. Most temperate plants store a large proportion of carbohydrates as starch in relatively stress-resistant propagules or plant parts, such as underground rhizomes, tubers, turions, or resistant stems. These structures resist extremes in weather as well as herbivory or control efforts. Examples of such starch-rich structures in aquatic plants include the rhizome of cattails and pond lilies (Nuphar advena Ait.), tubers of hydrilla (Hydrilla verticillata L.f. Royle) or sago pondweed, and root crowns of Eurasian watermilfoil. The advantage to the allocation pattern used by waterhyacinth is that carbohydrates are readily available for allocation to vegetative growth and flowering. However, waterhyacinth offsets the dangers of this allocation strategy by minor allocations to sexual propagation and by a more substantial allocation to long-term storage in the stembase, with up to 30 percent of whole-plant TNC in a relatively small amount of biomass. The stembase allows the plant to rapidly regrow from a single disturbance event, 


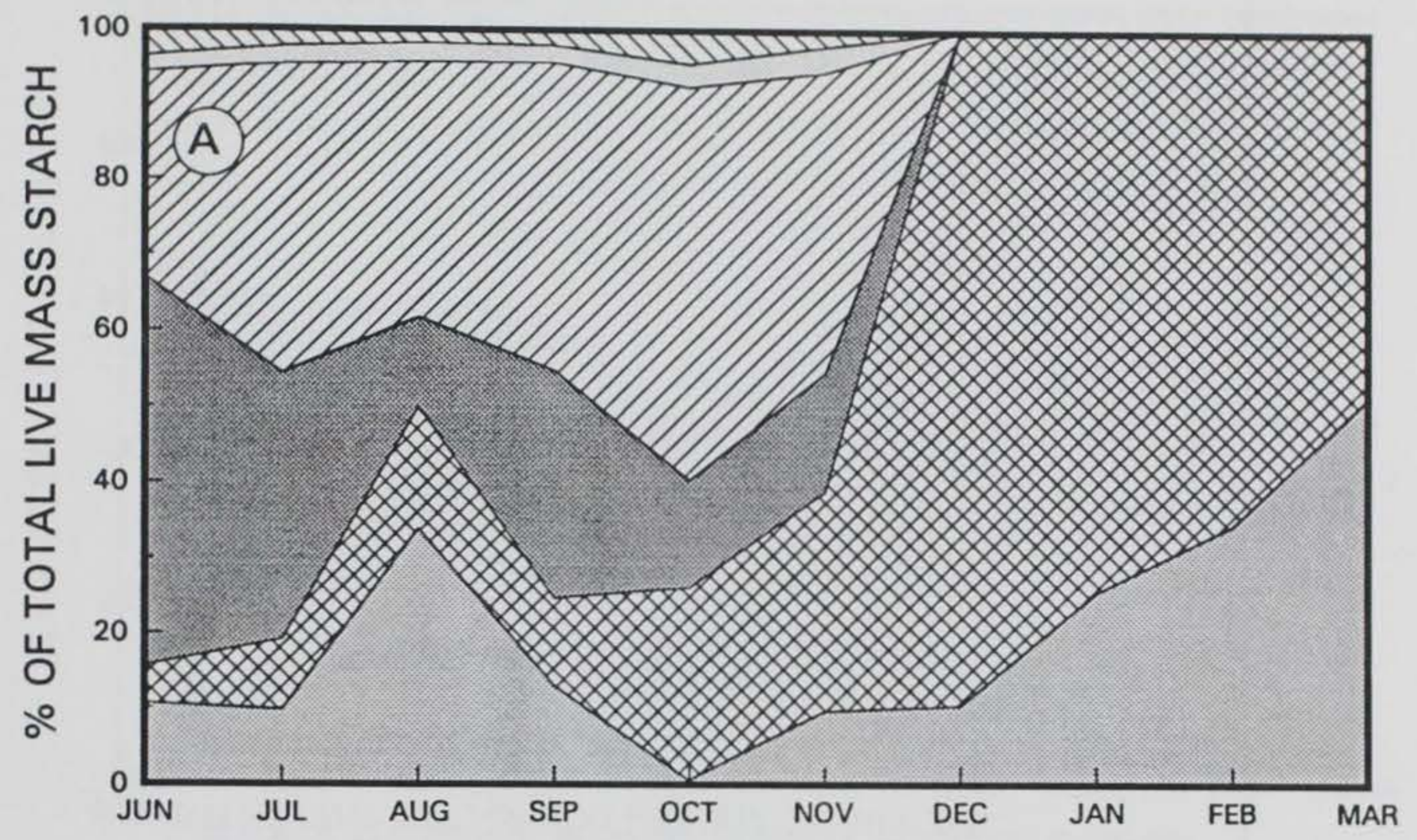

$\square$ ROOTS $囚$ STEMBASE $\square$ LAMINA $\square$ PETIOLE $\square$ STOLON $\square$ INFLOR.

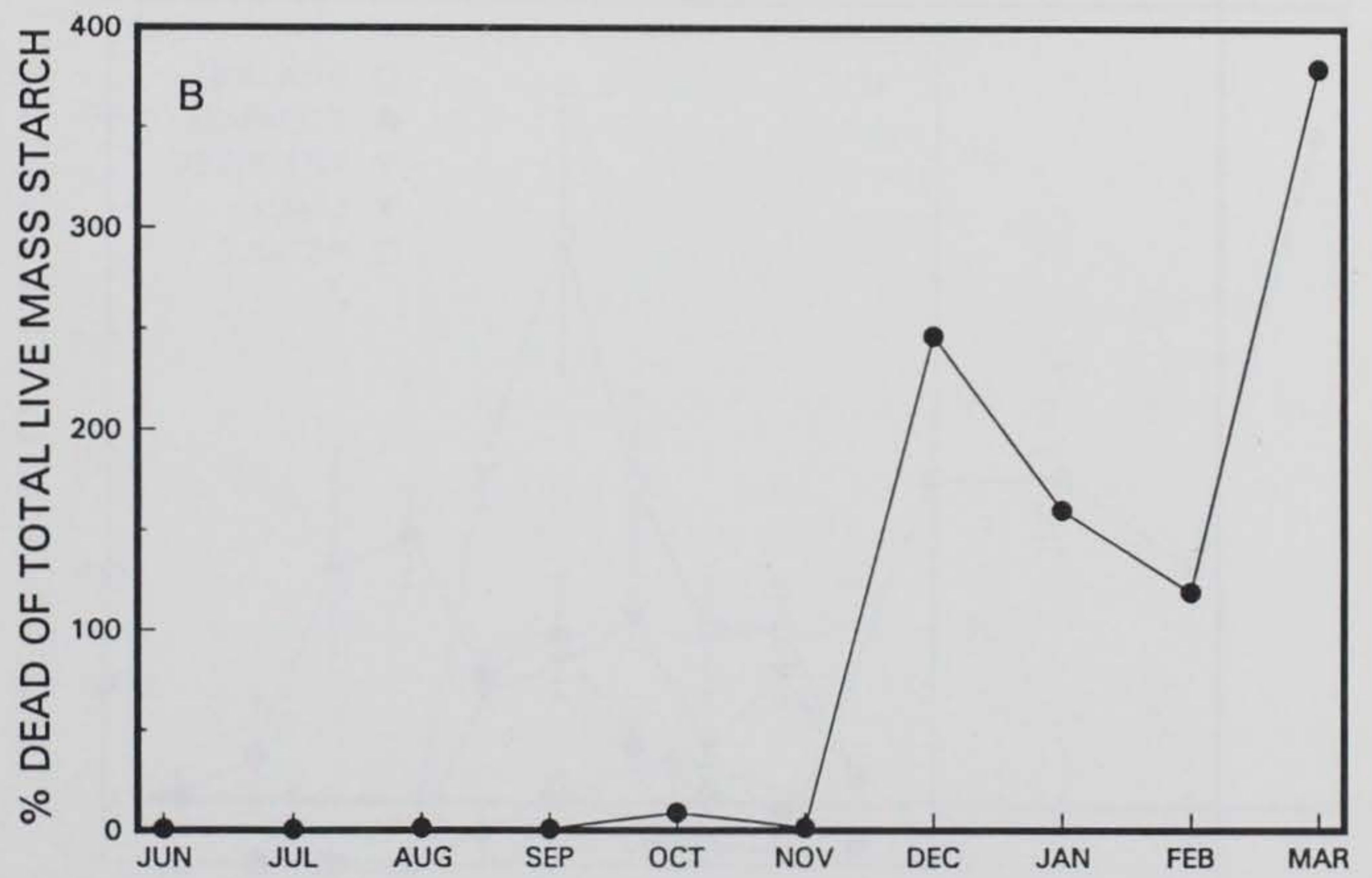

Figure 11. Plant part percent of total starch mass for living plant material $(A)$ and dead material starch mass as a percent of total live plant starch mass (B) 

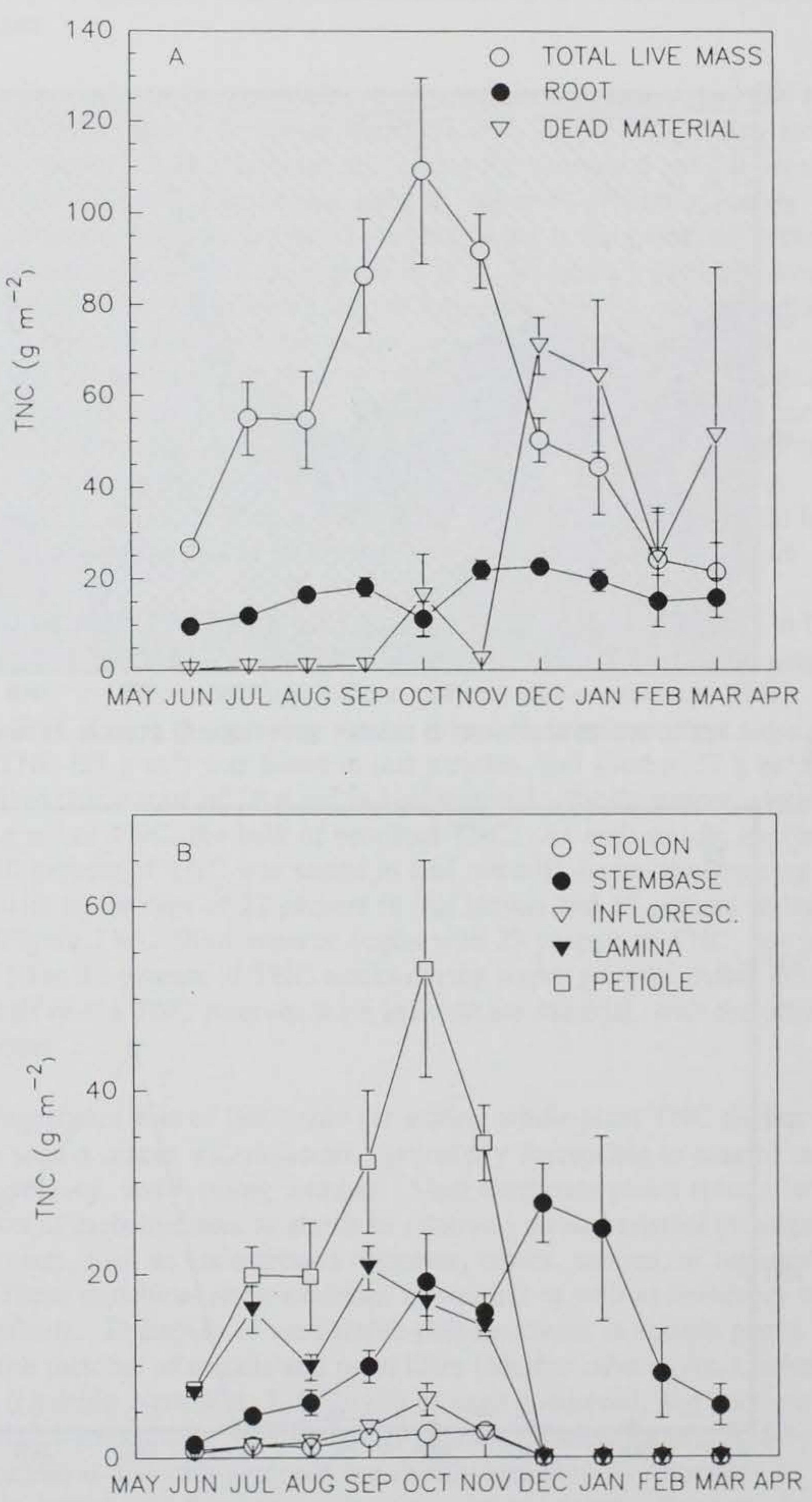

Figure 12. Total nonstructural carbohydrate mass per unit area of plant mass $\left(\mathrm{g} \mathrm{m}^{-2}\right)$ of total live mass, root, and dead material $(A)$ and of stolon, stembase, inflorescence, leaf lamina, and leaf petiole (B). Bar indicates \pm 1 standard error of the mean 


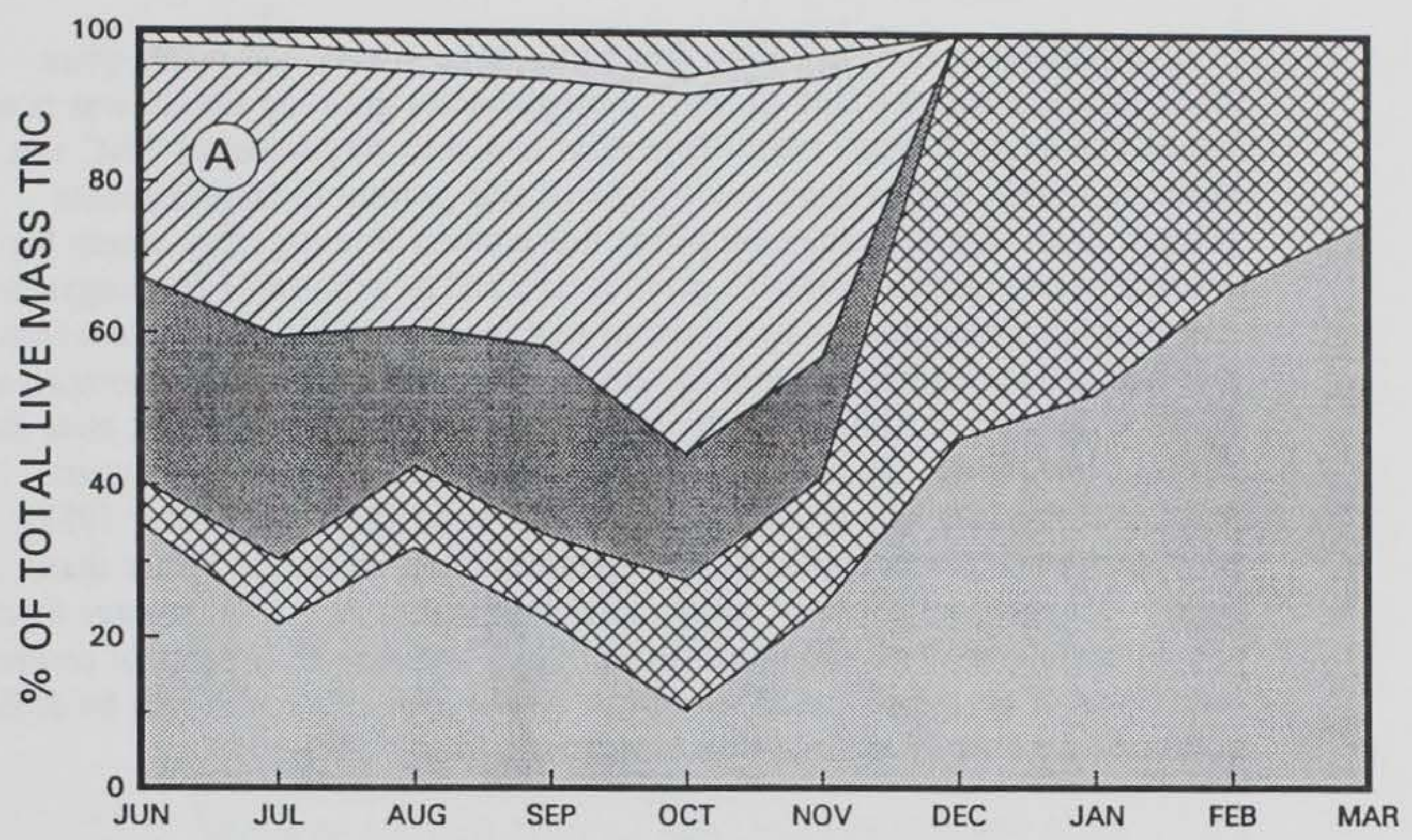

$\square$ ROOTS $\square$ STEMBASE $⿴ 囗 十$ LAMINA $\square$ PETIOLE $\square$ STOLON $\square$ INFLOR.

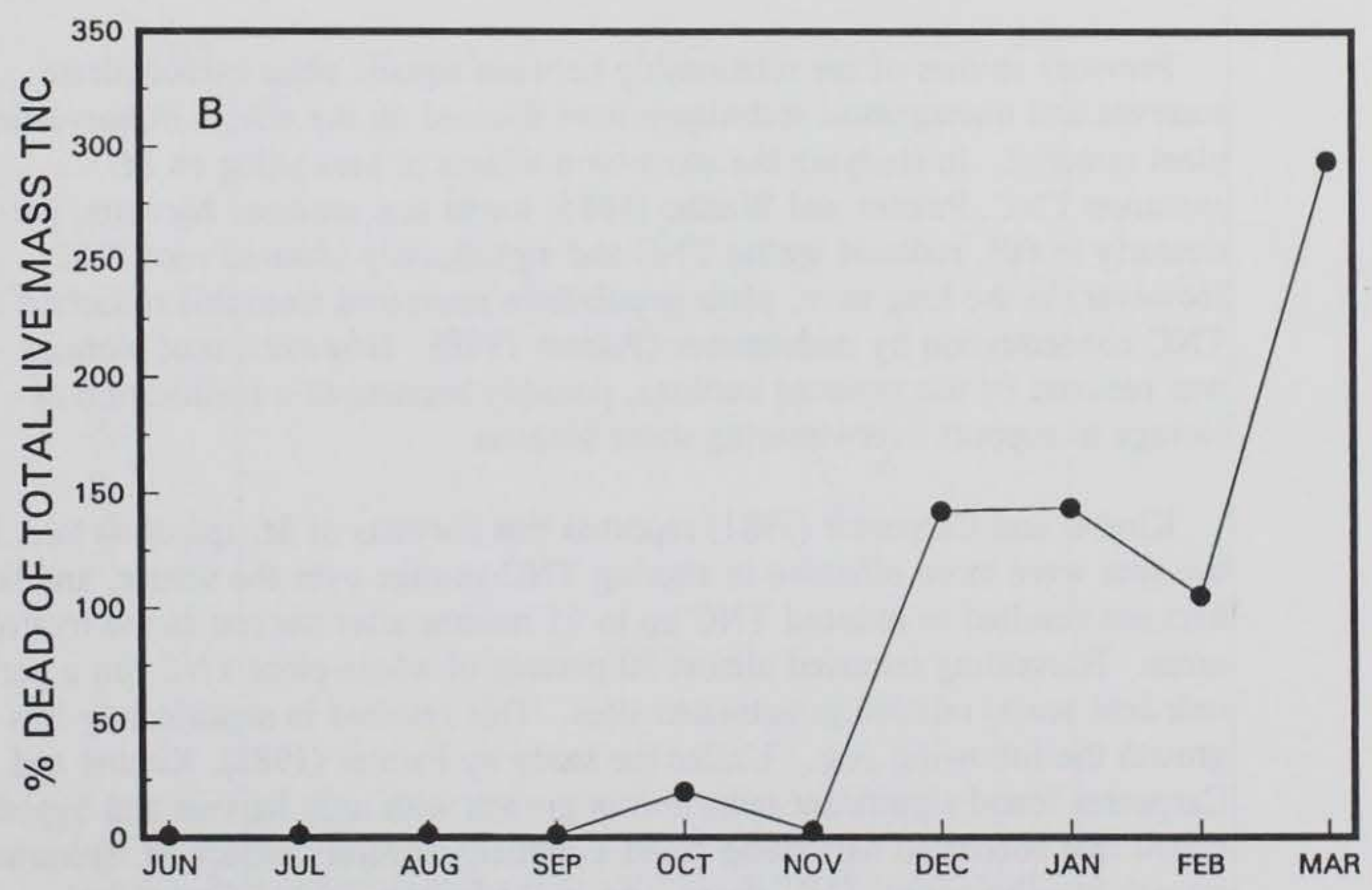

Figure 13. Plant part percent of TNC mass for living plant material $(A)$ and dead material TNC mass as a percent of total live mass TNC content (B) 
slight freeze, herbivory, or herbicide injury; however, it will not tolerate a substantial deep freeze such as observed in December of the study period.

Comparison of total live mass free sugar, total starch, and whole-plant TNC indicates that the bulk of TNC throughout the growing season was present as free sugar (Figure 14a). Typically, less than 30 percent of TNC was found as starch, except dead shoot material was present in large amounts (Figure 14b). Unlike temperate plants that convert free sugars to starch for winter, waterhyacinth maintains most of its TNC as exportable free sugar, to fuel biomass production or to export to new rosettes. This may be one reason that this species rapidly expands in new environments. Free sugar comprised 50 to 85 percent of TNC, with the minimum occurring in midwinter after the death of leaf tissue. In contrast, TNC of the temperate submersed aquatic plant $C$. demersum was 25 to 50 percent free sugar (Best and Visser 1987). Most temperate plants appear to store carbohydrates as starch, rather than sugar. The predominance of sugar rather than starch as a TNC storage form should make waterhyacinth more susceptible to multiple treatments of control techniques or the persistent attack of herbivores, since regrowth will be difficult once the bulk of leaf biomass is removed (Haag 1986).

\section{Management Strategies}

Previous studies of the relationship between aquatic plant carbohydrate reserves and management techniques have focused on the effects of harvesting plant material. In studying the short-term effects of harvesting on $M$. spicatum TNC, Painter and Waltho (1985) found that repeated harvests, particularly in fall, reduced spring TNC and significantly lowered root TNC. However, in the long term, plant populations recovered from this reduction in TNC concentration by midsummer (Painter 1988). However, root biomass was reduced by the repeated cuttings, possibly because of a reallocation of storage to support overwintering shoot biomass.

Kimbel and Carpenter (1981) reported that harvests of $M$. spicatum later in the year were more effective in altering TNC storage over the winter, and fall harvests resulted in reduced TNC up to 11 months after harvest in the treated areas. Harvesting removed almost 50 percent of whole-plant TNC (on a per unit area basis) relative to untreated sites. This resulted in significantly less growth the following year. Unlike the study by Painter (1988), Kimbel and Carpenter found significant reduction in growth with each harvest and hypothesized that continued harvesting could eventually severely reduce $M$. spicatum growth by eliminating TNC stores. As in the Painter study, Kimbel and Carpenter found fall harvests to be most efficient.

Perkins and Sytsma (1987) performed studies similar to those discussed above, on $M$. spicatum growing in Lake Washington. Using the idea that harvests should be performed when TNC was lowest, they performed 

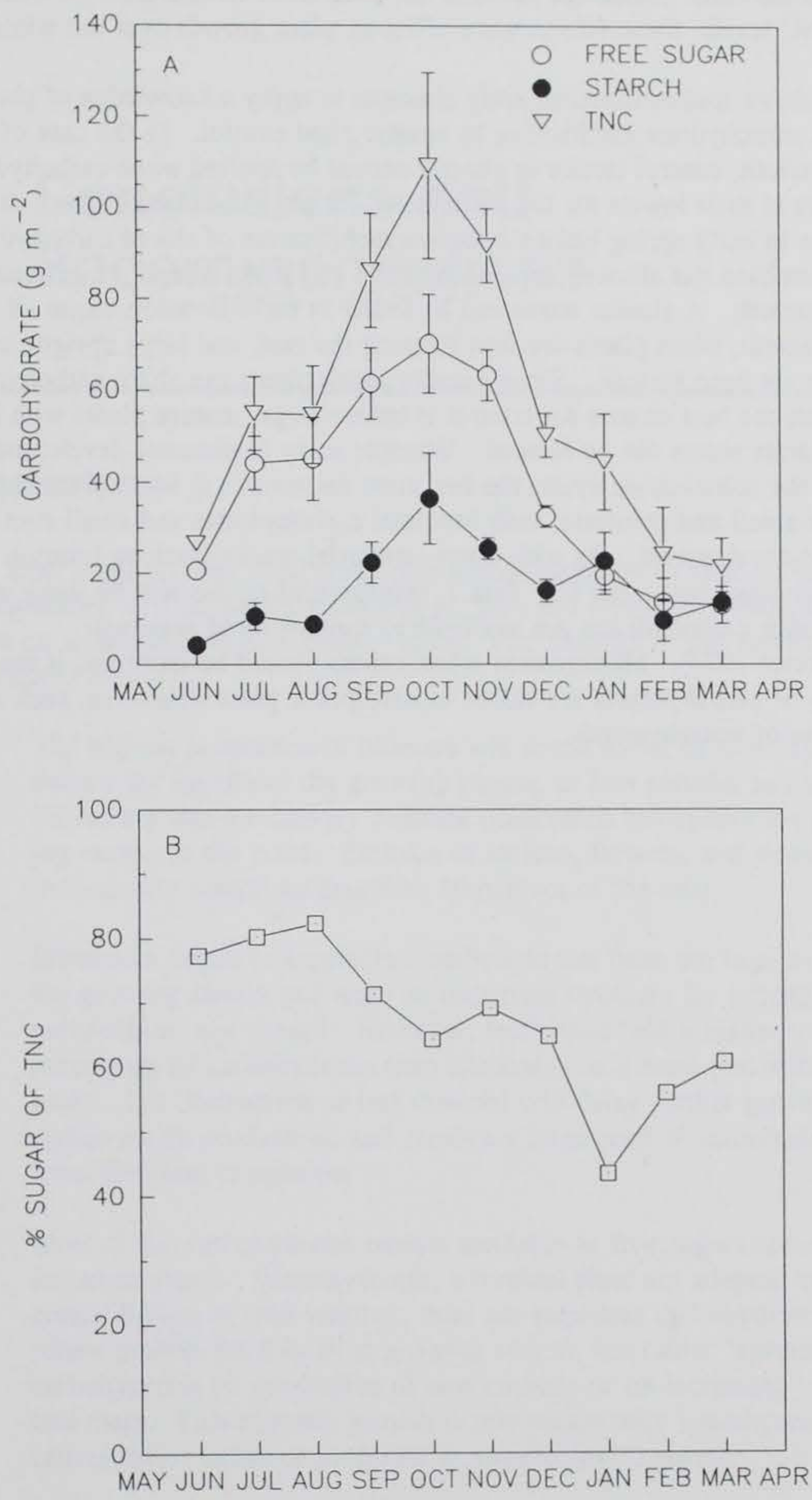

Figure 14. Total plant content $\left(\mathrm{g} \mathrm{m}^{-2}\right)$ of free sugar, starch, and TNC (A) and free sugar content as a percent of TNC (B). Bar indicates \pm 1 standard error of the mean 
early-fall harvests. Although harvests did have short-term effects on wholeplant TNC levels, these effects were offset by plant growth over the winter.

The above studies illustrate early attempts to apply a knowledge of phenology and carbohydrate partitioning to aquatic plant control. In the case of waterhyacinth, control tactics in general should be applied when carbohydrate stores are at their lowest for the population. In a typical mature stand, this would be in early spring before complete mobilization of stored carbohydrates in the stembase has allowed expansion of the leaf material and a maximum rate of growth. A similar status can be found in early-invasion stages of waterhyacinth, when plants are first forming the mat, and large upright leaves have not yet been formed. Since waterhyacinth plants can share carbohydrate resources, the best chance for control is before large, mature plants with large carbohydrate stores can be formed. Whether early in seasonal development or early in the colonization cycle, the best time for control is when plant populations are small and prostrate, with low total carbohydrates and small root and stembase development. As with many terrestrial weeds, such as Johnson grass (Sorghum halepense (L.) Pers.), management tactics will be more effective if fewer carbohydrates are available to support rapid regrowth (McWhorter 1974). Management effectiveness should be increased if the majority of carbohydrates are stored in susceptible plant structures, such as the leaves of waterhyacinth. 


\section{Conclusions and Recommendations}

\section{Conclusions}

In most respects, this pond study of seasonal variation in biomass and carbohydrates verified earlier studies (e.g., Luu and Getsinger 1990a,b) conducted on waterhyacinth at a smaller scale. The findings of this report are summarized below.

a. The highest proportion of biomass was found either as root mass or, toward the middle of the growing season, as leaf petioles and laminae. Flowering was a relatively constant occurrence throughout the growing season in the pond. Biomass of stolons, flowers, and stembases individually comprised less than 10 percent of the total.

b. Stembases began to accumulate carbohydrates from the beginning of the growing season and were an important structure for propagation, perennation, and spread. However, leaf tissue held a higher total percentage of carbohydrates than stembases on a mass per unit area basis. The destruction of leaf material will delay further growth and carbohydrate production, and remove a large pool of carbohydrates from the plant population.

c. Most of the carbohydrates remain available as free sugars rather than stored as starch. Waterhyacinth, a tropical plant not adapted to an annual period of cold weather, does not sequester carbohydrates to renew growth the following growing season, but rather "spends" the carbohydrates on production of new rosettes or on increasing vegetative mass. This rampant growth is one reason why waterhyacinth causes major nuisance problems in aquatic environments.

d. Frost events severely weaken waterhyacinth populations by eliminating the majority of the population's stored carbohydrates, in the leaves. If the weather warms again after a frost, permitting regrowth, the remaining plant material will be more susceptible to control efforts. 
e. Based on this pond study, one of the initial weak points in the waterhyacinth life cycle was substantiated: early in the growing season, before carbohydrate mass can accumulate for effective regrowth. An early-fall weak point was not evident in total plant TNC mass, but a shift in starch storage patterns in stembases was evident in early fall.

\section{Recommendations}

Based on the results from this study, recommendations are as follows:

a. Since leaf tissue contains a significant proportion of whole-plant TNC, damage or death to leaf tissue results in a significant reduction in the plants' ability to recover. Therefore, combining light herbicide applications with biocontrol efforts to slow growth rates (Haag, Glenn, and Jordan 1988; Center and Durden 1986) may be an effective technique from a physiological viewpoint.

b. Management tactics should attempt to control waterhyacinth populations while the plants are small, either early in the season when established populations are just recovering from overwintering or early in the invasion process when small prostrate rosettes predominate. Likewise, some management tactics might exploit low biomass in winter months.

c. Tactics applied at predetermined weak points in the life cycle of waterhyacinth should be examined on a demonstration scale at the LAERF, or similar sites, in order to apply our understanding of carbohydrate partitioning and growth dynamics to the more effective management of waterhyacinth. 


\section{References}

Alpert, P., Warembourg, F. R., and Roy, J. 1991. Transport of carbon among connected ramets of Eichhornia crassipes (Pontederiaceae) at normal and high levels of $\mathrm{CO}_{2}$. American Journal of Botany 78:1459-1466.

Best, E. P. H., and Visser, H. W. C. 1987. Seasonal growth of the submerged macrophyte Ceratophyllum demersum L. in mesotrophic Lake Vechten in relation to insolation, temperature and reserve carbohydrates. Hydrobiologia $148: 231-243$.

Center, T. D., and Durden, W. C. 1986. Variation in waterhyacinth/weevil interactions resulting from temporal differences in weed control efforts. Journal of Aquatic Plant Management 24:28-38.

Center, T. D., and Spencer, N. R. 1981. The phenology and growth of water hyacinth (Eichhornia crassipes (Mart.) Solms) in a eutrophic northcentral Florida lake. Aquatic Botany 10:1-32.

Cyr, D. R., Brewley, J. D., and Dumbroff, E. B. 1990. Seasonal dynamics of carbohydrate and nitrogenous components in the roots of perennial weeds. Plant, Cell and Environment 13:359-365.

Fitter, A. H. 1986. Acquisition and utilization of resources. In Plant ecology. M. J. Crawley, ed. Chap. 12. 375-405. Oxford: Blackwell Scientific Publications, Oxford.

Haag, K. M. 1986. Effective control of waterhyacinth using Neochetina and limited herbicide application. Journal of Aquatic Plant Management 24:70-75.

Haag, K. M., Glenn, M. S., and Jordan, J. C. 1988. Selective patterns of herbicide application for improved biological control of waterhyacinth. Journal of Aquatic Plant Management 26:17-19.

Hodgson, R. H. 1966. Growth and carbohydrate status of sago pondweed. Weeds 14:263-268. 
Holm, L. G. 1969. Weed problems in developing countries. Weed Science 7:113-118.

Holm, L. G., Plucknett, D. L., Pancho, J. V., and Herberger, J. P. 1977. The world's worst weeds; Distribution and biology. Honolulu: University Press of Hawaii.

Kimbel, J. C., and Carpenter, S. R. 1981. Effects of mechanical harvesting on Myriophyllum spicatum L. regrowth and carbohydrate allocation to roots and shoots. Aquatic Botany 11:121-127.

Kunii, H. 1989. Continuous growth and clump maintenance of Potamogeton crispus L. in Narutoh River, Japan. Aquatic Botany 33:13-26.

Larcher, W. 1980. Physiological plant ecology. 2 ed. Berlin: SpringerVerlag.

Linde, A. F., Janisch, T., and Smith, D. 1976. Cattail - The significance of its growth, phenology and carbohydrate storage to its control and management. Technical Bulletin No. 94. Madison, WI: Wisconsin Department of Natural Resources.

Luu, K. T., and Getsinger, K. D. 1988. Control points in the growth cycle of waterhyacinth. Information Exchange Bulletin A-88-2. Vicksburg, MS: U.S. Army Engineer Waterways Experiment Station.

Luu, K. T., and Getsinger, K. D. 1990a. Seasonal biomass and carbohydrate distribution in waterhyacinth. Journal of Aquatic Plant Management 28:3-10.

Luu, K. T., and Getsinger, K. D. 1990b. Seasonal biomass and carbohydrate distribution in waterhyacinth: Small-scale evaluation. Technical Report A-90-1. Vicksburg, MS: U.S. Army Engineer Waterways Experiment Station.

Madsen, J. D. 1991. Resource allocation at the individual plant level. Aquatic Botany 41:67-86.

McWhorter, C. G. 1974. Water soluble carbohydrates in Johnsongrass. Weed Science 22:159-163.

Nelson, N. 1944. A photometric adaptation of the Somogyi method for determination of glucose. Journal of Biological Chemistry 153:375-380.

Nichols, S. A. 1991. The interaction between biology and management of aquatic macrophytes. Aquatic Botany 41:225-252.

Painter, D. S. 1988. Long-term effects of mechanical harvesting on Eurasian watermilfoil. Journal of Aquatic Plant Management 26:25-29. 
Painter, D. S., and Waltho, J. I. 1985. Short-term impact of harvesting of Eurasian watermilfoil. In Proceedings, 1st international symposium on watermilfoil (Myriophyllum spicatum) and related Haloragaceae species.

23-24 July 1985, Vancouver, BC. 187-201. Vicksburg, MS: Aquatic Plant Management Society.

Penfound, W. T., and Earle, T. T. 1948. The biology of the water hyacinth. Ecological Monographs 18:448-472.

Perkins, M. A., and Sytsma, M. D. 1987. Harvesting and carbohydrate accumulation in Eurasian watermilfoil. Journal of Aquatic Plant Management 25:57-62.

Pesacreta, G. J., and Luu, K. T. 1988. Feasibility of relating phenology and carbohydrate partitioning to improve aquatic plant control. Miscellaneous Paper A-88-7. Vicksburg, MS: U.S. Army Engineer Waterways Experiment Station.

Schardt, J. D. 1990. The status of waterhyacinth and hydrilla in Florida waters-1985. Aquatics 12:13-14.

Swank, J. C., Below, F. E., Lamber, R. J., and Hageman, R. H. 1982. Interaction of carbon and nitrogen metabolism in the productivity of maize. Plant Physiology 70:1185-1190.

Titus, J. E., and Adams, M. S. 1979. Comparative carbohydrate storage and utilization patterns in the submersed macrophytes, Myriophyllum spicatum and Vallisneria americana. American Midland Naturalist 102:263-272.

Tucker, C. S., and DeBusk, T. A. 1981. Seasonal growth of Eichhornia crassipes (Mart.) Solms: Relationship to protein, fiber, and available carbohydrate content. Aquatic Botany 11:137-141.

Westover, R. S., and Madsen, J. D. 1992. Seed germination and seedling survival of waterhyacinth. In Proceedings, 26th annual meeting, Aquatic Plant Control Research Program. Miscellaneous Paper A-92-2. 129-132. Vicksburg, MS: U.S. Army Engineer Waterways Experiment Station. 
Public reporting burden for this collection of information is estimated to average 1 hour per response, including the time for reviewing instructions, searching existing data sources. gathering and maintaining the data needed, and completing and reviewing the collection of information. Send comments regarding this burden estimate or any other aspect of this Davis Highway, Suite 1204, Arlington, VA $22202-4302$, and to the Otfice of $M$

\begin{tabular}{|l|l|l|}
\hline 1. AGENCY USE ONLY (Leave blank) & $\begin{array}{c}\text { 2. REPORT DATE } \\
\text { January } 1993\end{array}$ & $\begin{array}{l}\text { 3. REPORT TYPE AND DATES COVERED } \\
\text { Final report }\end{array}$ \\
\hline
\end{tabular}

\section{TITLE AND SUBTITLE}

Allocation of Biomass and Carbohydrates in Waterhyacinth

(Eichhornia crassipes): Pond-Scale Verification

\section{AUTHOR(S)}

John D. Madsen, Kien T. Luu, Kurt D. Getsinger

WU 32441

\section{PERFORMING ORGANIZATION NAME(S) AND ADDRESS(ES)}

U.S. Army Engineer Waterways Experiment Station, Environmental Laboratory, 3909 Halls Ferry Road, Vicksburg, MS 39180-6199

\section{SPONSORING / MONITORING AGENCY NAME(S) AND ADDRESS(ES)}

U.S. Army Corps of Engineers,

5. FUNDING NUMBERS

Washington, DC 20314-1000

\section{SUPPLEMENTARY NOTES}

Available from National Technical Information Service, 5285 Port Royal Road, Springfield, VA 22161.

12a. DISTRIBUTION/AVAILABILITY STATEMENT

12b. DISTRIBUTION CODE

Approved for public release; distribution is unlimited.

\section{ABSTRACT (Maximum 200 words)}

Currently, little biologically based understanding exists for the optimum timing of control tactics, with respect to time of year and stage of growth of target plant. A better understanding of plant life cycles and carbohydrate allocation patterns may elucidate weak points in the life cycle of target plants and allow optimum application of control measures.

The objectives of this study were to verify previous small-scale waterhyacinth carbohydrate allocation studies in a large pond environment and to elucidate carbohydrate and biomass allocation patterns in waterhyacinth (Eichhornia crassipes (Mart.) Solms).

Waterhyacinth was grown in a 0.3-ha pond near Lewisville, TX, from June 1989 to March 1990. Monthly plant samples were taken and sorted into component plant parts (i.e., leaf petioles, leaf laminae, stolons, stembases, roots, inflorescences, and dead material), which were then analyzed for free sugars, starch, and total nonstructural carbohydrates (TNC).

(Continued)

\begin{tabular}{|c|c|c|c|}
\hline \multicolumn{3}{|l|}{ 14. SUBJECT TERMS } & $\begin{array}{c}\text { 15. NUMBER OF PAGES } \\
39\end{array}$ \\
\hline \multicolumn{3}{|l|}{ See reverse. } & 16. PRICE CODE \\
\hline
\end{tabular}




\section{3. (Concluded).}

Maximum plant biomass ranged from 991 to $1,146 \mathrm{~g} \mathrm{~m}^{-2}$ during the period July through November 1989 . Leaves and roots were the highest proportion of living plant mass, followed by stembases. Leaves were composed of 60 to 65 percent petioles and 35 to 40 percent laminae. A heavy frost in December killed above-water plant parts, mostly leaves.

Carbohydrate concentrations were highest in stembases (up to 40 percent TNC), followed by stolons (15 percent); other plant parts were 10 percent or less. TNC mass per unit area was highest in leaf petioles before the frost, and in stembases after the frost. During the growing season, 60 percent of TNC was found in the leaf tissue on a per unit area or total plant weight basis, whereas only 20 percent was stored in the stembase. After frost, most of the plant's TNC was found in the stembase, since the TNC stored in the leaves was lost as dead material.

The primary weak point in the life cycle of waterhyacinth, defined as the time of lowest whole-plant TNC stores, was observed in the early summer, before plants had built up sufficient carbohydrate reserves to provide for regrowth. A secondary period of potential low recovery would be in early fall, before a large proportion of total plant carbohydrates is stored as starch in the stembase. In general, control will be more effective when applied to small colonies not yet developed into mature stands, whether early in the year or early in the invasion or recovery cycle.

\section{4. (Concluded).}

Allocation
Biomass
Carbohydrates
Eichhornia crassipes
Life cycle

Allocation

Biomass

Eichhornia crassipes

Life cycle

\author{
Phenology \\ Starch \\ Waterhyacinth \\ Weak points
}

